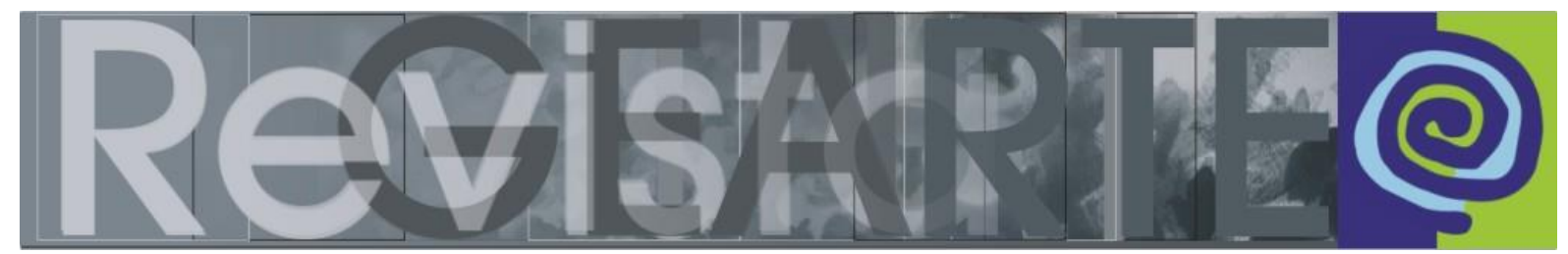

ISSN 2357-9854 | e-ISSN 2596-3198 (online)

\title{
De ponta-cabeça: \\ descobrir percepções sensíveis pelos olhos de aspirantes a professores
}

\author{
Mirian Celeste Martins ${ }^{(D)}$ \\ (Universidade Presbiteriana Mackenzie — MACKENZIE, São Paulo/SP, Brasil)
}

\begin{abstract}
RESUMO - De ponta-cabeça: descobrir percepções sensíveis pelos olhos de aspirantes a professores - Os pés no ar, de ponta-cabeça, são um convite à leitura deste texto que se propõe a problematizar os termos aluno, estudante e aspirante à docência e suas conexões com modos de ensinar e aprender; a adentrar na prática da observação de produções infantis; a viver uma pedagogia da escuta sensível, criativa e rizomática ao provocar percepções e análises pautadas em narrativas reflexivas, proposições ampliadoras e ações poéticas. A docência, a criação, a pesquisa e a arte modelam este texto a/r/tográfico na esperança de desvelar a experiência, a prática pedagógica e seus fundamentos e o desafio de aprofundá-los.
\end{abstract}

PALAVRAS-CHAVE

Arte. Pedagogia. Formação de professores. Observação. Pedagogia da Escuta.

\begin{abstract}
Upside down: discover sensitive insights through the eyes of aspiring teachers - Feet in the air, upside down, is an invitation to read this text that proposes to problematize the terms pupil, student and aspiring to teacher and their connections with ways of teaching and learning; to get involved in the practice of observing children's productions; to live a pedagogy of sensitive, creative and rhizomatic listening by provoking perceptions and analyzes based on reflective narratives, expanding propositions and poetic actions. Teaching, creation, research and art shape this $a / r /$ tographic text in the hope of unveiling experience, pedagogical practice and its foundations and the challenge of deepening them.
\end{abstract}

KEYWORDS

Art. Pedagogy. Teacher Formation. Observation. Listening Pedagogy.

RESUMEN - Al revés: descubra conocimientos sensibles a través de los ojos de los futuros profesores - Pies en el aire, al revés, son una invitación a la lectura de este texto, que propone problematizar los términos alumno, estudiante y aspirante a docente y sus conexiones con las formas de enseñar y aprender; involucrarse en la práctica de observar producciones infantiles; vivir una pedagogía de escucha sensible, creativa y rizomática provocando percepciones y análisis a partir de narrativas reflexivas, proposiciones expansivas y acciones poéticas. La enseñanza, la creación, la investigación y el arte dan forma a este texto a/r/tográfico con la esperanza de desvelar la experiencia, la práctica pedagógica y sus fundamentos y el desafío de profundizarlos.

PALABRAS CLAVE

Arte. Pedagogía. Formación de profesores. Observación. Pedagogía de la escucha. 


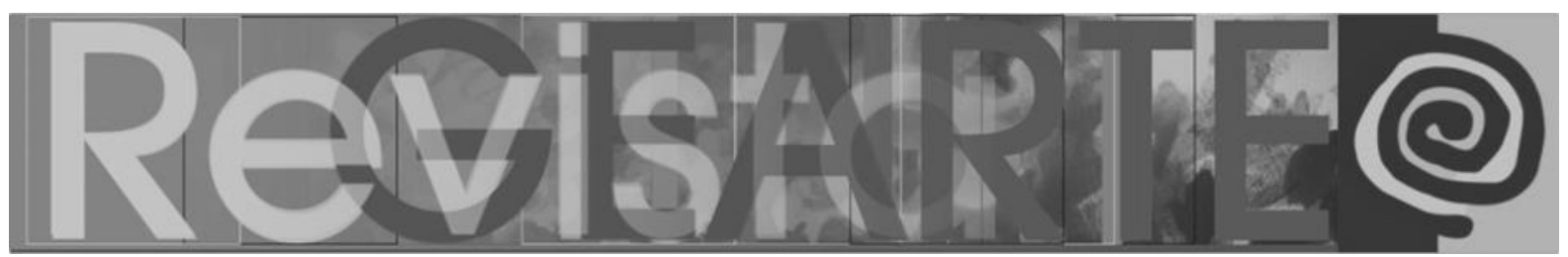

Figura 1 - Com os pés no ar

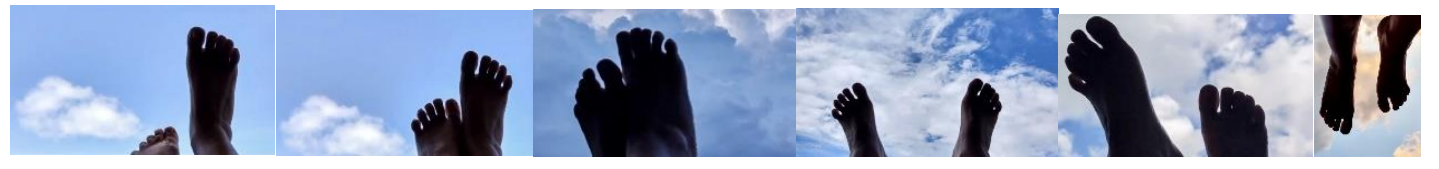

Fonte: Marcia Strazzacappa, $2020{ }^{1}$

[...] não basta inverter o olhar, é preciso colocar-se na condição graças à qual aquela paisagem possa desvelar-se, fazer mais um esforço contra 0 nosso corpo: é preciso ir lá, caminhar nela, mergulhar nela sem preconceitos culturais, fazer dessa paisagem uma experiência direta. Há um belíssimo verbo em alemão que explica tudo: spazieren, caminhar, passear, mas acima de tudo eu diria "espaciar", produzir espaço caminhando (CARERI, 2017, p. 126).

Para ler o último capítulo de Caminhar e parar, de Francesco Careri (2017), do qual retiro as palavras que abrem este texto, temos de virar o livro de pontacabeça. Um convite para uma experiência direta na própria leitura. Marcia Strazzacappa ${ }^{2}$ também nos coloca de ponta-cabeça em seu vídeo Com os pés no ar (2020), realizado em pleno recolhimento imposto pelo Covid 19 e onde diz: "Na ausência de asas, aprendi a caminhar sobre as nuvens. Um passo de cada vez".

Espaciar, produzir espaço caminhando, refletir caminhando tentando mergulhar em uma paisagem que, embora do cotidiano docente, nos provoca um olhar de ponta-cabeça. É esse o convite deste texto, escrito em uma perspectiva a/r/tográfica (IRWIN, 2008; DIAS; IRWIN, 2013), em que a docência, a criação e a arte se movem e pinçam no caminhar sobre a experiência vivida aspectos da prática para aprofundar e partilhar.

Os pés no ar, de ponta-cabeça, convidam-nos a apresentar, inicialmente, uma paisagem, o contexto em que me situo para problematizar os termos aluno, estudante e aspirante à docência e suas possíveis relações com os modos de ensinar e aprender, trazendo a prática da observação das produções infantis para provocar percepções sensíveis e proposições atentas aos aprendizes. Um exercício que move não só os universitários do curso de Pedagogia, mas também esta professora, girando para ver de cabeça para baixo. 


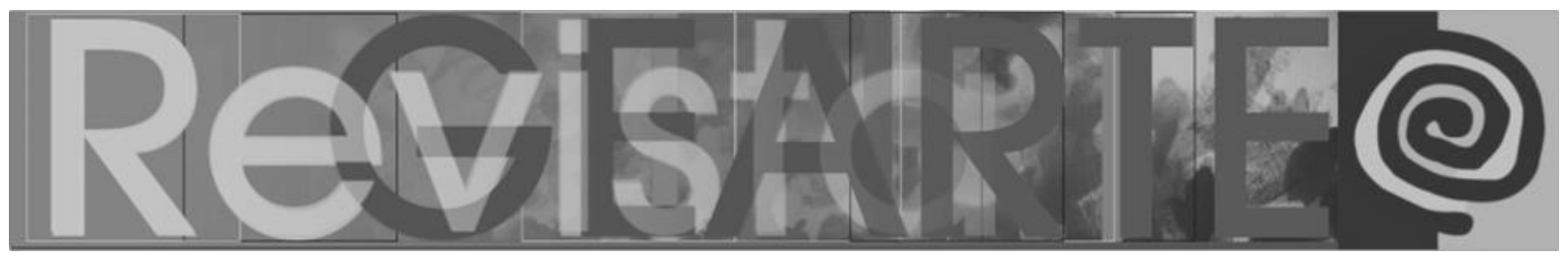

\section{Uma possível inversão na paisagem conhecida}

Alunos são alunos. Aprenderam em suas longas vidas pela escola a produzir trabalhos de acordo com o que é solicitado. Gostariam de intuir o que, exatamente, a professora quer para fazer dentro dos moldes almejados? Notas são para passar de ano?

Lembro-me dos questionários no fim dos livros de história em que a tarefa era buscar no texto lido o trecho que respondia à pergunta e apenas copiá-la. Ou dos problemas de matemática com um único modo de resolver, ou de gramática das línguas que estudávamos, nas quais a tarefa era utilizar os conceitos aprendidos e não escrever expressivamente ou ler o que poderia ser mais interessante para compreender a cultura de um povo. Ou das aulas de arte com atividades definidas, como o círculo das cores primárias (que naquele tempo eram apenas vermelho, azul e amarelo), ampliação de figuras, autocontraste etc. E cabia ao professor aferir os resultados. Certo e errado são marcas duras, assim como o bonito ou o feio para um trabalho de artes ou, talvez, o bem ou malfeito...

Os tempos mudaram e as avaliações puderam se tornar formativas, isto é, não é só o produto final que conta, mas todo o processo. Entretanto, alunos e alunas continuam a buscar responder certeiramente ao que é solicitado e, para isso, gostam da precisão da proposta. Quantas linhas ou quantas laudas é uma pergunta ainda comum...

Essa mesma atitude parece estar presente quando universitários do Curso de Pedagogia, em seus estágios, focalizam mais as atividades definidas pelos professores do que as respostas e as aprendizagens das crianças. Ou quando têm de planejar ações para as crianças, selecionando atividades que pouco levam em conta o grupo de crianças a quem são dirigidas. Atividades isoladas a serem cumpridas... Assim como nos semanários que podem ser constatados em muitas escolas. 


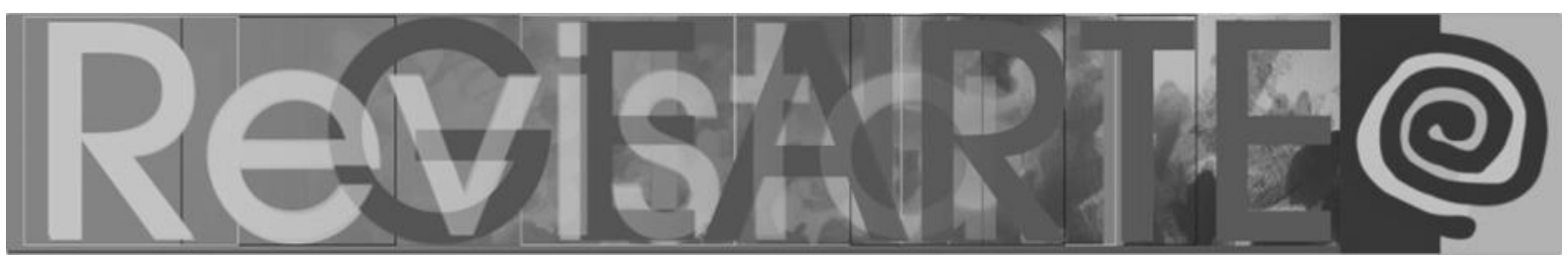

Como professora responsável pela disciplina Fundamentos Teóricos e Metodológicos do Ensino de Arte e Alfabetização Estética, essa situação tem me levado a muitas experiências docentes. A disciplina passou por reformulações de nomeação à carga horária, mas trago neste texto a experiência de 23 turmas que por mim passaram nestes 13 anos de atuação na Universidade Presbiteriana Mackenzie, depois de me aposentar trabalhando na formação específica em Artes, além de outras tantas ações docentes ${ }^{3}$.

Nos cursos de bacharelado e de licenciatura em Arte, os universitários já chegam com uma vivência sensível e compreensão pessoal sobre arte e cultura, o que justamente os fez escolher esse caminho profissional. Tenho encontrado um panorama completamente diferente naqueles que escolhem o Curso de Pedagogia. Raramente tiveram uma vivência, frequentação ou compreensão da arte e cultura, e isso nos tem levado a buscar uma docência que ofereça uma vivência sensível e criativa em relação às linguagens artísticas e, ao mesmo tempo, ao estudo e à compreensão da potência da produção infantil em sua metamorfose expressiva e às necessárias ações docentes. E ainda com carga horária reduzida. Dura tarefa já presente em tantos documentos desde a década de 1980, com os iniciadores dessa luta, como Mariazinha Fusari, Olga Reverbel e tantos outros. E que nos fizeram criar o GPAP - Grupo de Pesquisa Arte na Pedagogia, que, desde 2012, vem levantando e compartilhando questões, pesquisas (MARTINS; LOMBARDI, 2015) e seminários internacionais desenvolvidos também pelo GPeMC - Grupo de Pesquisa em Mediação cultural: contaminações e provocações estéticas (MARTINS; MOMOLI; BONCI, 2018; MARTINS; FARIA; LOMBARDI, 2019).

Deparei-me com essa situação quando mergulhei no Curso de Pedagogia. A experiência anterior na formação continuada de coordenadores e professores de Educação Infantil e séries iniciais tinha outro sabor, porque elas e eles traziam suas preocupações, dúvidas e questionamentos sobre o seu fazer cotidiano com as artes. Como lidar com o tempo reduzido e a amplidão de conceitos, conteúdos, práticas e metodologias? Como possibilitar sustentação a um "exercício de prática docente enquanto sensível, criativa e interdisciplinar", como sintetiza Estela Bonci 


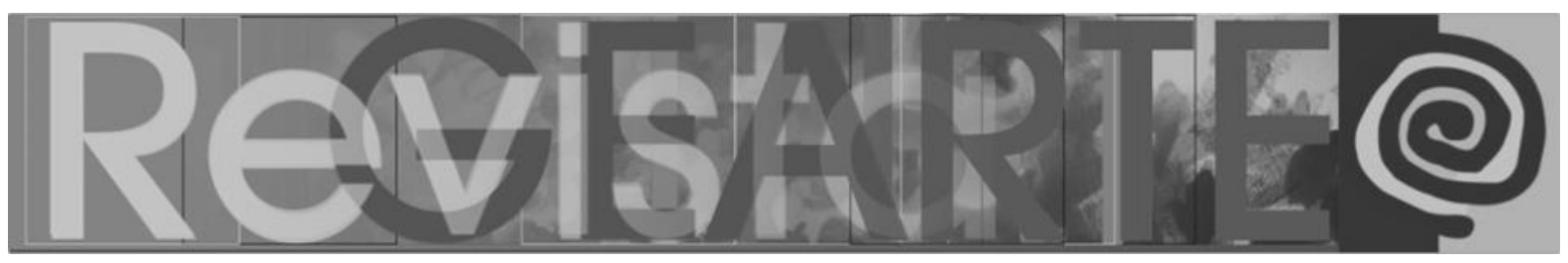

(2018) em sua pesquisa de doutoramento, que focalizou a formação cultural e artística de estudantes do Curso de Pedagogia?

Já há algum tempo, tenho desenvolvido a disciplina em quatro campos: Arte (suas linguagens e campo de conhecimento); Aprendizes (seu desenvolvimento expressivo); Metodologias (teorias e práticas no ensino de arte) e Experiências estésicas (ações poéticas dedicadas à vivência de experiências pessoais como adultas e adultos). Muitas são as reflexões e as práticas já realizadas e que se tornaram textos compartilhados em revistas e congressos acoplados, muitas vezes, ao conceito de mediação cultural, outro dos meus temas de trabalho e estudo permanente.

É neste panorama complexo, incerto e sempre inovado a cada nova turma, que me movo e giro como artógrafa, docente, pesquisadora e criadora.

Em um 'giro', nos afastamos de algo ou nos movemos em direção ou em torno de algo, e somos nós que estamos nos movendo, e não o próprio objeto. Quando nos movemos, algo é ativado dentro de nós, talvez até atualizado (ROGOFF, 2011, p. 261).

É nesse giro que problematizações vêm à tona...

\section{Sobre alunos, estudantes e aspirantes à docência}

Alunos são aqueles que assistem às aulas. Estudantes são aqueles que estudam, aqueles que mergulham na compreensão. Essa distinção foi apontada pela minha orientanda Márcia Maria Arco e Flexa Ferreira da Costa ${ }^{4}$, que me apresentou o professor Pierluigi Piazzi (2008). Por um viés de neurociência, ele aponta a importância do estudar não para a prova, mas para compreender, valorizando o desenvolvimento da inteligência, e assim distingue "alunos" de "estudantes".

Estudantes vão construindo conceitos sempre passíveis de serem ampliados, articulados com outros, superados, descartados, aprofundados, na perspectiva 


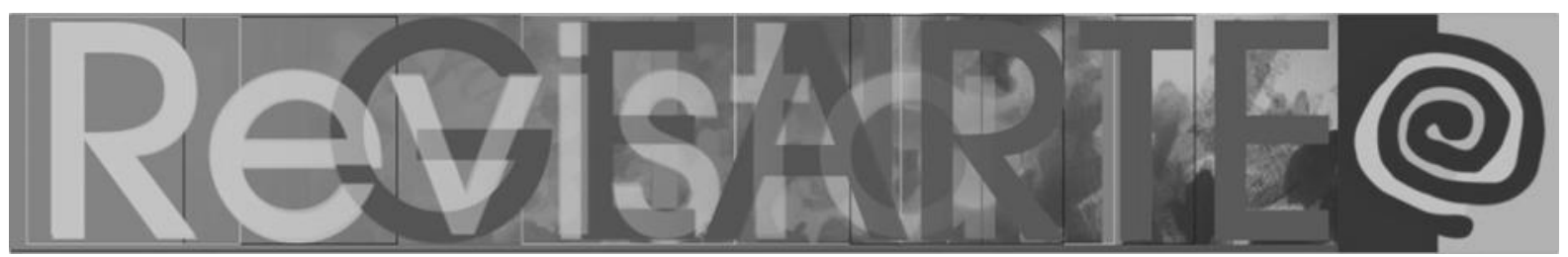

rizomática de múltiplas conexões. Para isso, a curiosidade parece ser um gatilho. Encontro ressonância em um dos poemas sobre o estudar de Larossa (2003):

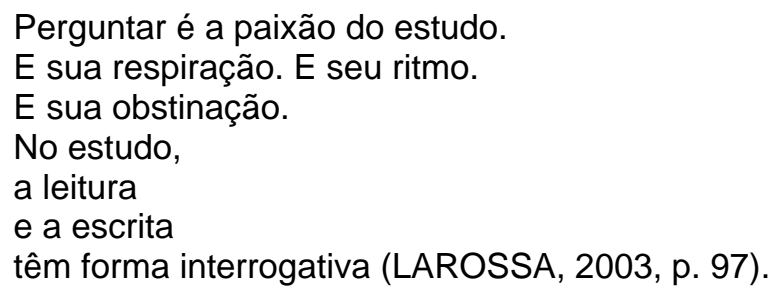

Estudar, escrever, ler perguntando... Escrita em forma interrogativa... É isto que nos move como eternos aprendizes. Percebo que cada texto iniciado vai construindo sua própria narrativa na resposta às questões que vão surgindo, além de buscar na memória experiências e autores que nos levam a aprofundá-las e a encontrar outras perguntas... e assim continuamos aprendizes.

Universitários ou acadêmicos são aqueles que estudam em uma universidade, mas considerá-los como estudantes parece indicar um modo de percebê-los em ações mais produtivas e menos passivas. Parece os colocar como responsáveis também pelo o quê e por quanto realmente estudam. Entretanto, encontro em Rita Irwin (2016) uma outra faceta: em vez de aluno ou estudante de um curso de formação de educadores, ela os coloca como "candidatos à docência". O que isso pode significar?

No texto Becoming A/r/tography, referindo-se a uma pesquisa, Rita Irwin (2016, p. 25, tradução nossa) declara: "Iniciamos essa investigação viva de Tornarse pedagógico, encorajando os candidatos a professores a questionar suas intenções/ações relacionadas a instrumentos de seu contexto e experiências adquiridas ao longo do programa". Na citação, a condição de "candidato a professor" credita a ele o envolvimento em aspectos pessoais e sociais de conhecimento, tornando-o um pesquisador, aprendendo como observar, questionar, analisar e interpretar.

Em resposta ao meu e-mail sobre o uso do termo, Rita Irwin comentou que ele é usado na University British Columbia, em Vancouver, no Canadá, e que não MARTINS, Mirian Celeste. De ponta-cabeça: descobrir percepções sensíveis pelos olhos de aspirantes a professores. 231 Revista GEARTE, Porto Alegre, v. 8, n. 2, p. 226-252, maio/ago. 2021.

Disponível em: http://seer.ufrgs.br/gearte 


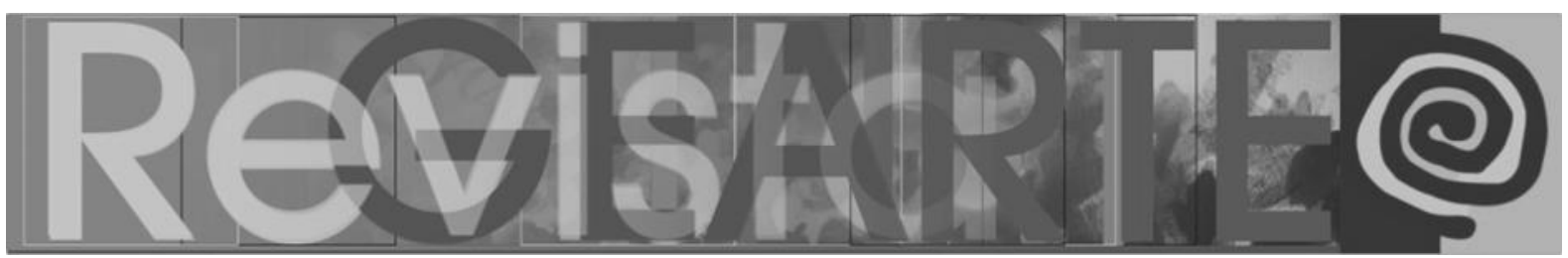

tem informações sobre quando começou a ser utilizado. Para ela, o termo enfatiza que os estudantes tomem a si a responsabilidade de se ver como professores já em sua formação. "Descobrimos que os ajuda a pensar mais seriamente sobre no que estão embarcando", escreveu ela ${ }^{5}$.

Como o termo "candidato", entre seus significados, tem relação com uma eleição para um cargo ou função, proponho o termo "aspirante a professor". Expus essa ideia para Rita Irwin, que valorizou a escolha do termo apropriado ao nosso contexto e idioma. Considerar nosso universitário do Curso de Pedagogia como um aspirante a professor o coloca em outro nível, questionando suas intenções e ações, envolvendo-o com a construção de seu próprio conhecimento, indo além do ensinar a ensinar.

Cabe aos aspirantes a professor, mais do que saber planejar aulas, criar sequências didáticas, estudar autores que possam assessorar sua ação e ler os documentos oficiais. Mas como ir além do que imaginam ser em uma boa aula de arte? Ou do que já viveram em arte? O que sabem sobre a produção infantil? Como vislumbrar o que seria um professor-propositor?

É sobre uma prática específica que sigo essa reflexão a partir dessas constatações e questionamentos.

\section{Uma proposição provocadora}

Alunos esperam tarefas. Artistas recebem encomendas. Talvez possa fazer diferença encomendar ações pedagógicas aos aspirantes a professoras e professores, como sempre receberam os artistas ao longo do tempo. Mudanças nos termos não são apenas um nome novo para a mesma ação, mas, conceitualmente, desvelam uma concepção repleta de significações. É nesse sentido que tenho usado o termo e me faz lembrar a história que me foi contada quando o pano de boca feito por Picasso foi apresentado na exposição Parade - 100 Anos de Arte - 1901-2001, realizada no Pavilhão Lucas Nogueira Garcez (Oca), no Parque Ibirapuera, em São Paulo. Sergei Diaghilev, diretor de uma importante companhia russa de balé, 


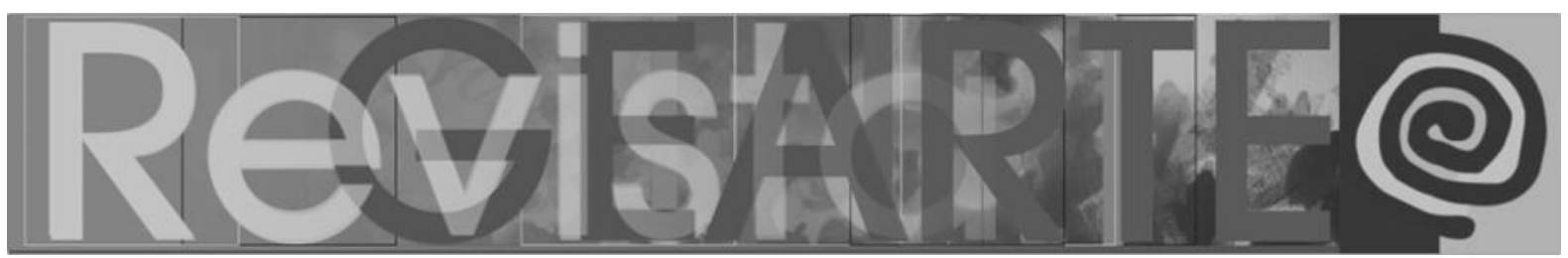

desafiou Cocteau a escrever um argumento; o compositor Erick Satie, a música; e a Picasso, a fazer os cenários, os figurinos e o pano de fundo do balé Parade, que estreou em 1917. Disse ele: "Surpreenda-me".

Talvez seja esta boa surpresa que esperamos de nossos aspirantes quando Ihes damos uma encomenda criativa. E tenho me surpreendido com o resultado de uma ação que venho perseguindo: a atuação direta com crianças. Em seus estágios, isso tem sido impossível, e também percebo diferença se podem atuar com uma criança ou um pequeno grupo. Assim, elas e eles têm de buscar uma criança ou grupo de crianças para essa encomenda.

Inicialmente, a encomenda seguia a metodologia de projetos que tem sido minha ação docente há tempos. Em meu doutorado (MARTINS, 1999), orientada pela querida e saudosa Mariazinha Fusari, pesquisei a relação entre projetos de artistas e de educadores a partir dos depoimentos de uma artista - Regina Silveira -, de um educador de educadores - Fernando Hernández -, de uma educadora Rosane Acedo Vieira - e de uma aspirante a educadora - Cláudia Pereira da Silva. Viver projetos é vivenciar processos que são como a arte, "um tal fazer que enquanto faz inventa o por fazer e como fazer", como diz Pareyson (1994, p. 32).

Guardo comigo exemplos muito ricos de projetos que também se alinham a uma perspectiva a/r/tográfica, pois é um processo que foi se arquitetando no percurso, com muita criação, pesquisa e envolvimento por parte de todos. Guardo também exemplos de quando o tempo não foi suficiente ou não foi bem aproveitado para desvelar/ampliar a produção da criança, para viver uma pedagogia da escuta sensível, criativa e rizomática. Para driblar a questão do tempo e da teimosia em deixar para a última hora o contato com crianças, o que tornaria o projeto mais superficial, simplifiquei a encomenda nestes dois últimos semestres.

É essa a prática que trago neste texto, escolhido porque me fez olhar de ponta-cabeça, estudando o modo como aspirantes a professores observam, pensam e agem frente à produção das crianças e como ampliar a compreensão 


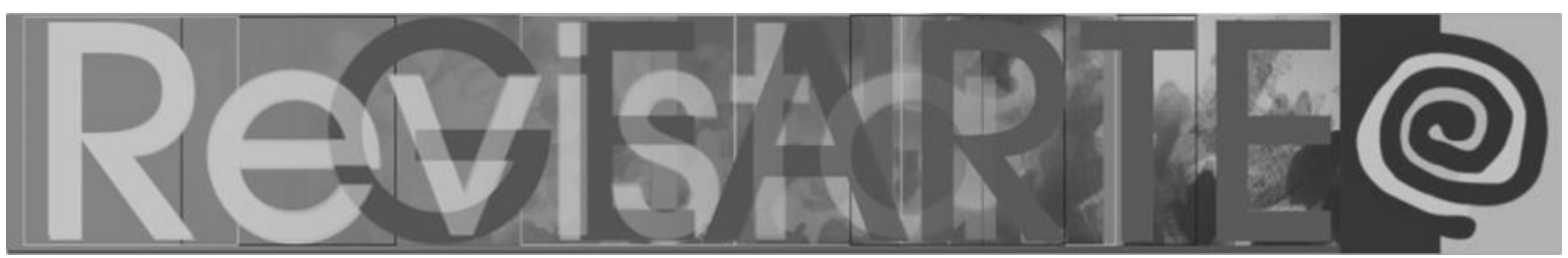

sensível e embasada. Importante citar também que, concomitantemente às ações e aos diálogos sobre os textos e as produções infantis, viviam ações poéticas em que operavam com os meandros das linguagens artísticas.

Neste semestre, iniciei com o curta metragem premiado Love hair. A história de um pai afro-americano que teve que pentear a filha pela primeira vez foi criada por Mathew A. Cherry. Foi comprada pela Sony Pictures, virou livro e ganhou o prêmio de curta-metragem do Oscar de 2020. Selecionei imagens de trechos nos quais se veem os desenhos da criança espalhados pelo quarto e o que escolhe como presente para a mamãe. Todos já recebemos desenhos de presente e sabemos o que significam para nós e para as crianças. E já na primeira aula pedi um portfólio com memórias da infância, o que tenho feito há anos.

Vimos também o documentário Caminhando com Tim Tim (2014), com a direção de Tiago Expinho, o pai do pequeno menino Valentim em seu caminho cotidiano até a casa da avó junto com sua mãe, Genifer Gerhard, palhaça e bonequeira. Diz ela no vídeo: "Valentim tem me ensinado sobre os caminhos, caminhares e destinos; que o chegar não é mais valioso que a andança; que o encontro é valioso e necessário" (CAMINHANDO..., 2014).

Lemos o texto O menininho, de Helen Buckley (2005), que evidencia o poder dos modelos impostos pelo adulto e, além de falar sobre a encomenda, escrevi um texto para que as turmas pudessem reler com calma antes de mergulhar na observação:

1. Encontre uma criança para observá-la desenhando. Se possível, recolha ou fotografe desenhos anteriores... O mais importante é deixar a criança desenhar como sempre faz e assim é preciso tomar cuidado com fotos ou filmagens, pois isto pode distrair, embaraçar ou mesmo amedrontar a criança. Você precisa pedir autorização dos pais para usar as imagens da criança, ou usar ângulos em que o rostinho não seja identificado.

2. Você pode dar tipos diferentes de papéis, tanto pequenos como postit, por exemplo, como papéis enormes, mas cuidado: a pesquisa não é para distraí-la, mas perseguir seus gestos, seu corpo em movimento. Você pode oferecer lápis preto, de cores, giz de cera, tintas, argila, etc. e ver o que ela prefere utilizar. E convide a continuar depois de terminar o primeiro... 


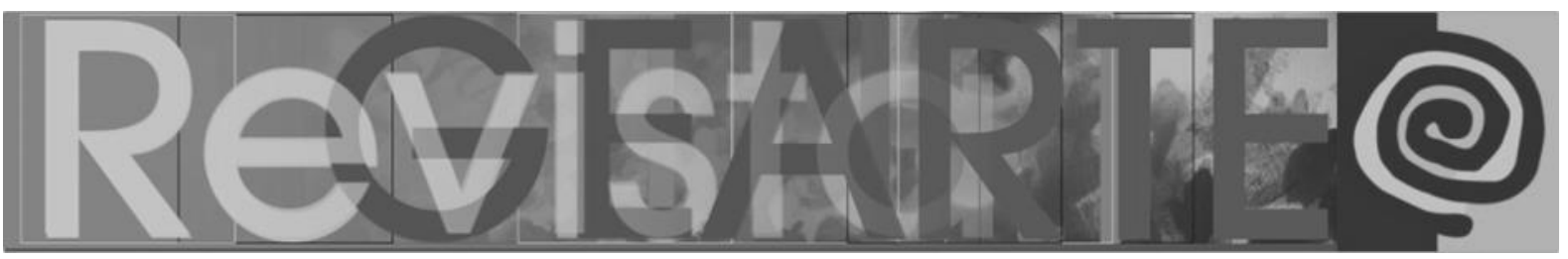

3. Se possível, não a deixe atenta a você. Seja invisível, se puder... Talvez você não saiba o que observar, mas preste atenção nas escolhas que a criança faz no meio do processo, perceba a ordem do que vai colocando no papel, especialmente nas garatujas. Anote o que ela vai falando. E não fale que está "bonito". Temos de tirar este termo de nosso vocabulário de professores. Há outros modos de elogiar para incentivar!

4. Um diálogo pode ampliar a conversa sobre o que vai aparecendo no papel, mas cuidado para não dirigir ou "ensinar" algo... O diálogo nasce do que ela fala e do que vai aparecendo em seu desenho, mas não fique ansiosa para logo falar... Deixe que o desenho nasça, veja as "paradas", acompanhe o ritmo... "Que linha forte você fez! E que comprida!". "O que a sua menina está segurando nas mãos?" (supondo ela desenhou uma menina e poderia desenhar também algo na mão, para que a ação apareça no desenho).

5. Escreva um texto (visual/verbal) com suas observações, não esquecendo de apresentar a criança (idade, se estuda e onde, com quem vive, seu grau de relacionamento com ela), do contexto em que foi feita a observação (local, duração, o que foi oferecido como material e suporte) e detalhando o que percebeu sobre o processo de criação da criança. Para encerrar, escreva sobre as descobertas e dificuldades na observação e pense: que desafios você poderia propor a esta criança? (BUCKLEY, [2005], n.p.).

Exemplos podem deixar mais clara esta prática que me faz olhar também de ponta-cabeça, pois nos interessa ver a leitura que aspirantes a professores fazem da produção infantil que acompanham. É uma experiência, grifada com itálico, tal qual faz Dewey (2010). Uma leitura de ponta-cabeça que investiga o professor ou aspirante a professor, que olha e ouve a criança em seu desenhar. É isso que podemos investigar trazendo pequenos trechos de alguns dos textos sobre as observações. 


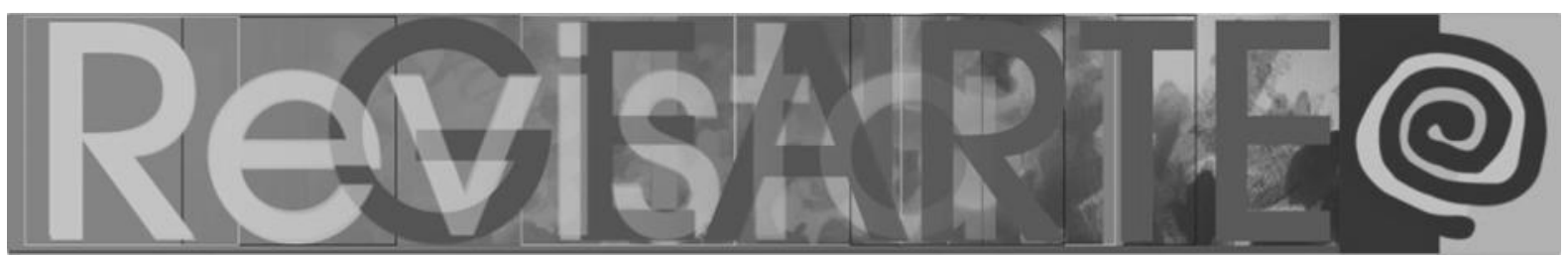

\title{
Percepções sensíveis, surpresas e aprendizagens
}

Figura 2 - Observando Manoel (3a, 11m) a desenhar

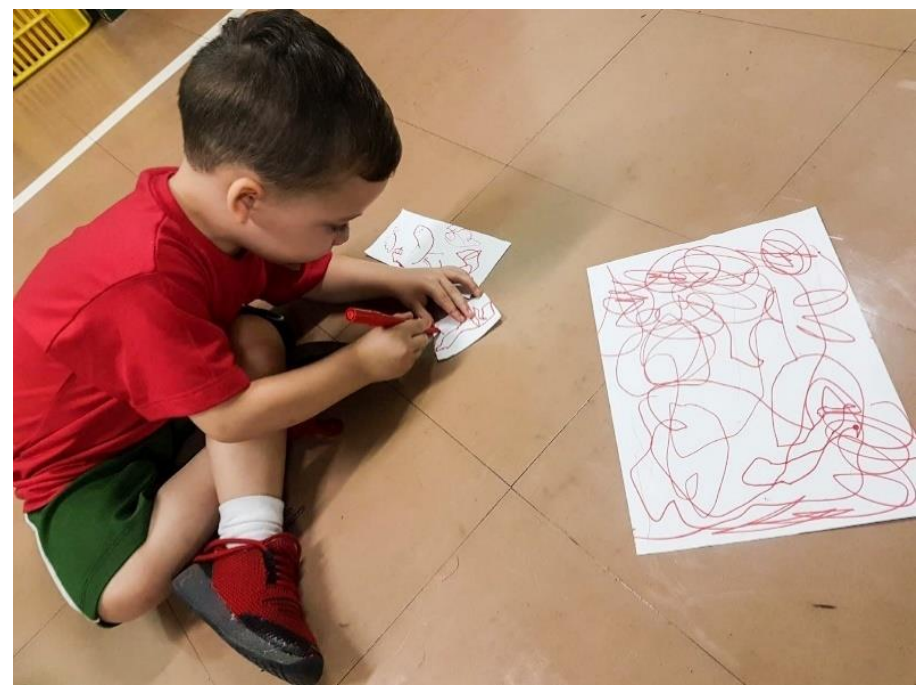

Fonte: Maria Isabelli Nuci de Oliveira, 2020.

O que vemos nos três desenhos de Manoel em seus 3 anos e 11 meses?

Certamente, garatujas com boa exploração espacial, experimentação de muitas das 20 garatujas básicas e um padrão de disposição global segundo Rhoda Kellog (1985). Se soubéssemos o que ele comentou enquanto desenhava, poderíamos também dizer que é uma garatuja identificada na perspectiva de Lowenfeld e Britain (1977). Olhando o produto, seriam possíveis essas análises, mas o que escreve Maria Isabelli Nuci de Oliveira, em 2020, ao observar seu priminho?

\begin{abstract}
Sem tirar a canetinha da folha ele continuava dizendo o que era, do Pokémon, ele mudou para um balão, foi para um dinossauro, em seguida para uma montanha, na qual ele olhou o desenho da prima do lado e quis fazer igual, no entanto incrementou coisas que não tinha no desenho dela, como parquinhos. Correndo por toda a folha ele dizia que dava para brincar em todos os lugares, enfatizando que tinha muitos parques, falando que era colorido, mesmo continuando só com o vermelho.

Depois dei uma tira da folha sulfite, reduzindo então o espaço dele, mesmo com essa mudança a canetinha vermelha continuou na sua mão, e começou desenhando novamente um Pokémon, mas desta vez falando que era um Pokémon sapequinha.

Por último dei a ele só um quadradinho de folha, e com o mesmo material, ele diz que estava fazendo desta vez um dinossauro, e logo em seguida ao observar o desenho rapidamente ele muda sua ideia para um Pokémon com um monte de pernas.
\end{abstract}




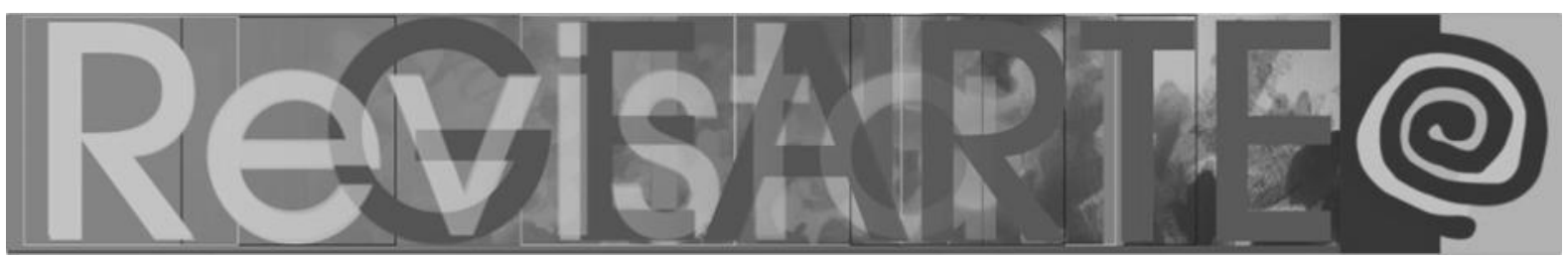

Há um universo mágico que nossos olhos não poderiam imaginar ao ver os três desenhos. É isso que encanta Maria e todos os que ouvem a leitura de sua observação. Inédito para elas pensar que aqueles rabiscos "são" tantas personagens, animais, lugares, tudo tão colorido, mesmo que só com a caneta vermelha. Algo que surpreende também ao ver a pintura de um menino de 3 anos. Exploração com pincel com sobreposição das cores verde, azul e um pouco de amarelo. Movimentos ordenados longitudinais e até mesmo um princípio de mandala acima à esquerda. Mas o que nos conta Carolaine Deodato de Souza, em relato de 2019 ?

Figura 3 - Pintura de Miguel (3a)

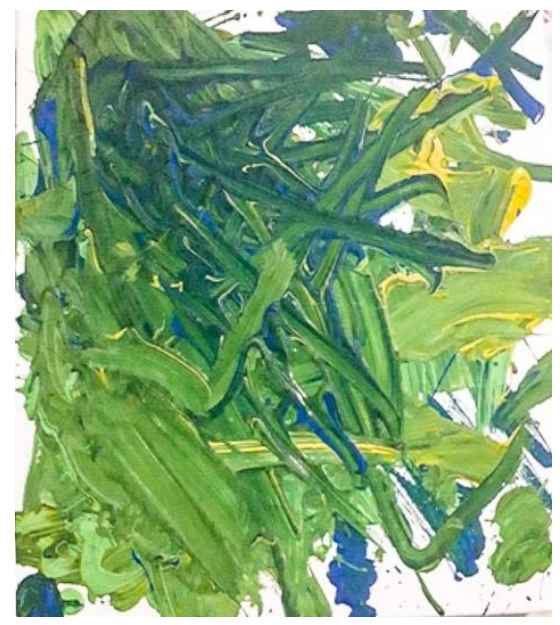

Fonte: Carolaine Deodato de Souza, 2019.

Iniciando a observação eu perguntei para o Miguel o que ele gostaria de desenhar, e em seguida ele me respondeu dizendo que seria um arcoíris, mas falou que não sabia desenhar e me pediu para desenhar. Falei para ele fazer o desenho do jeito que ele soubesse. Achei interessante porque o arco-íris tem diversas cores e ele tinha apenas 3 cores. Ele começou seu arco-íris tentando fazer traços alinhados, logo após ele pintou por cima do arco-íris somente de azul e falou que iria desenhar um círculo em amarelo; em seguida, ele resolveu pintar o amarelo de azul e eu, sem entender, perguntei o por que, e ele me respondeu que o sol tinha ido embora e que as nuvens tinham escondido ele e com o verde ele fez diversos pontos, dizendo ser a chuva, e retornando com o amarelo, o sol novamente tinha aparecido. Durante o processo, ele começou a cantar uma cantiga infantil: "A cobra não tem pé? Não. E como que ela sobe no pezinho de limão? Estica, encolhe, seu corpo é todo mole", e ao mesmo tempo desenhando em movimento de sobe e desce; e novamente resolvi perguntar e ele disse que era uma cobra. Essa observação levou uns 30 minutos para poder ser concluída. [...] Como citei, achei que ele não faria um desenho tão criativo porque não coloquei as cores que para minha percepção seriam azul do céu e chuva, amarelo 


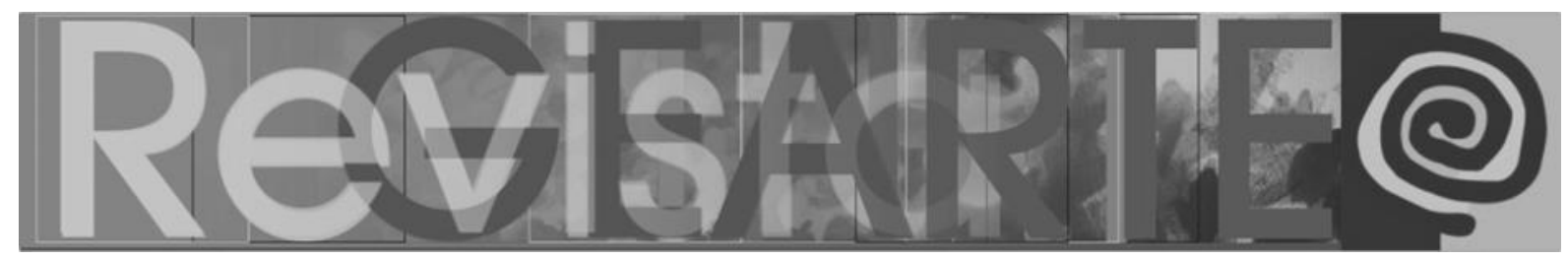

do sol, verde das plantas, marrom da terra, vermelho e rosa das flores. Ele usou o que tinha para fazer, desenhos que por algum motivo vieram na sua cabeça; me espantei quando ele encobriu o amarelo, pois não imaginei que pintando por cima do amarelo de azul significaria que sol estaria indo embora.

É na descrição do que viram nascer no papel que Maria Isabelli e Carolaine puderam perceber e compreender melhor a produção infantil dos pequenos e superar a ideia de garatujas como simples rabiscos aleatoriamente jogados no papel e a importância de acompanhar seus movimentos, que evidenciam seus interesses, seus saberes e as histórias que vão relembrando e criando no fazer.

Para ampliar a compreensão, apresentei 0 vídeo ${ }^{6}$ do meu neto Felipe (3a,10m) desenhando na lousa verde em amplos gestos e descobrindo que pode desenhar com os dedos tirando o giz e também com o apagador. No meio de sua produção, resolve que quer desenhar uma casa, mas diz que não sabe e pede para que eu ensine. Apenas pergunto "O que tem em uma casa?". E ele me responde desenhando do seu modo uma forma irregular com muitas formas dentro. Pergunto onde está a campainha e assim descobri onde era a porta. E ele continua a contar que está chovendo e há trovões, pois naquela época chovia muito em São Paulo.

Figura 4 - Desenhos de Felipe (3a, 10m)

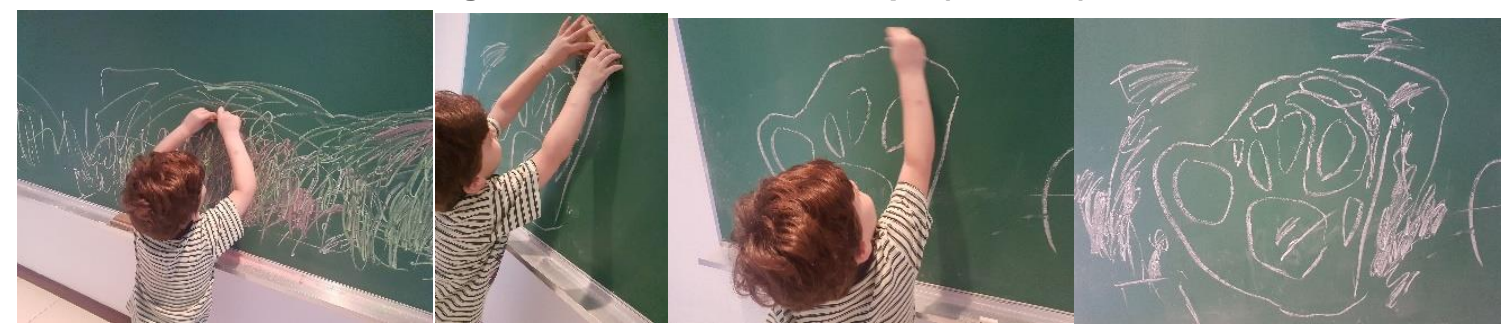

Fonte: Mirian Celeste Martins, 2019.

É visível que é na ação de observar que a surpresa da potência infantil se revela e produz rupturas na perspectiva do que uma garatuja pode nos contar sobre a criança e o início de sua apropriação da linguagem da arte nascida no exercício, na pesquisa e na ação, plena do movimento que envolve todo o corpo. 


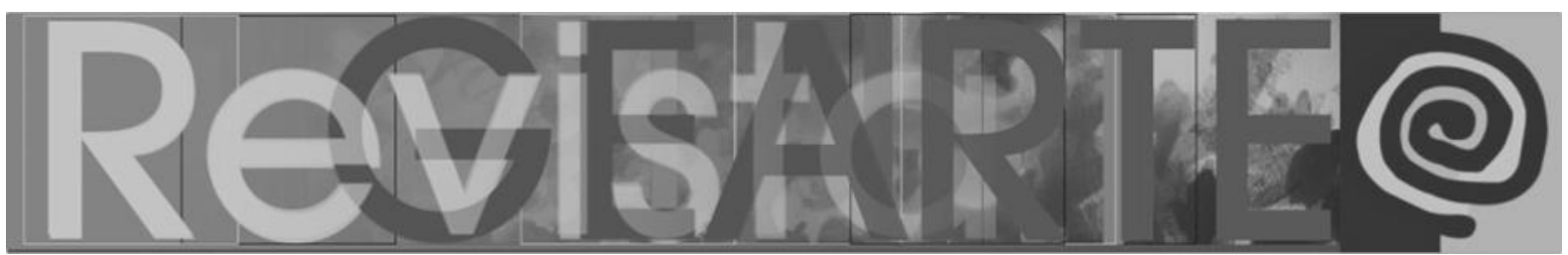

O mesmo acontece com desenhos mais figurativos. O que vemos no desenho abaixo? O que a criança falou enquanto desenhava? A observação de Emily Bomfim Souza foi primorosa no diálogo compartilhado com uma criança de 4 anos.

Figura 5 - Desenho de Hayanne (4a)

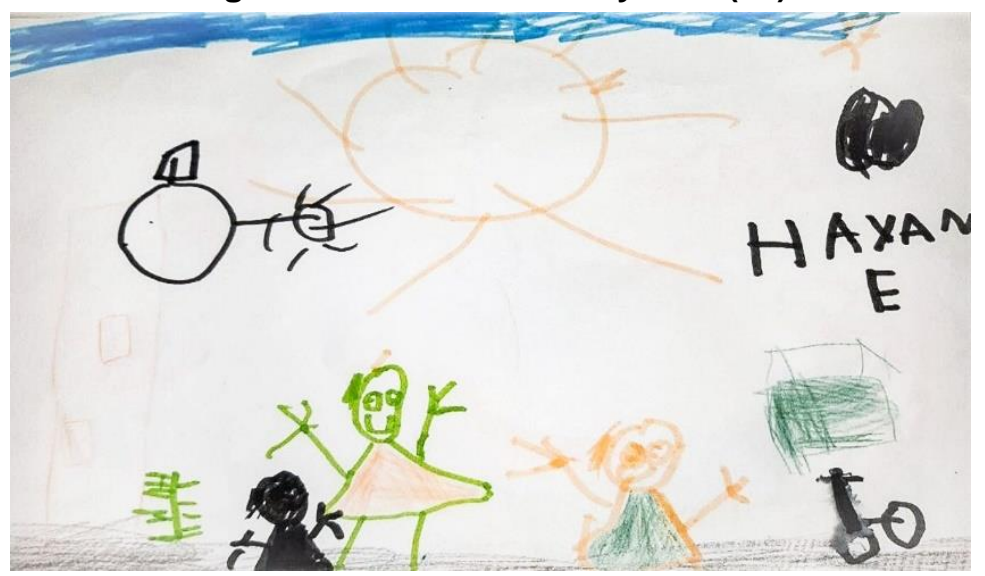

Fonte: Emily Bomfim Souza, 2019.

- Vou desenhar aqui uma menina que estava em cima da casa e caiu, "tchbumm".

- Mas ela não vai se machucar?

- Nãooo! Você não viu o helicóptero?! É para salvar as crianças que não obedecem a mamãe. Ele salvou ela e colocou no rio, e o jacaré comeu ela, assim ó: "Inhack"!

- Mas onde está o jacaré?

- Ali ó, atrás da flor. Viu?! Que susto, né?! O jacaré tem um bocão e come tudo até as crianças, sabia? (narrando e desenhando o jacaré).

Sério?

- É... Mas não tenho medo do jacaré....

- Por quê?

- Eu não vou ficar em cima da casa! (informação verbal) ${ }^{6}$

Histórias fantásticas povoam o desenho, do qual poderíamos pouco falar se víssemos apenas o produto, se não soubéssemos todo o processo. Para Gardner (1999), aqui está a "idade de ouro do desenho", pois tudo é possível, não há barreiras, como se pode ver também no relato de Carolina Ribeiro de Souza, em 2020.

Confesso que me surpreendi um pouco com como ela desenha e seu jeito de se expressar. [...] Laila utilizou apenas as canetinhas e percebi que logo já iniciou seu desenho, sem pensar muito e ao longo do desenho a maior parte do tempo, falava em voz alta passo a passo do que estava colocando em seu desenho, como se estivesse explicando para avó [que enviou o vídeo para a sua observação]. 


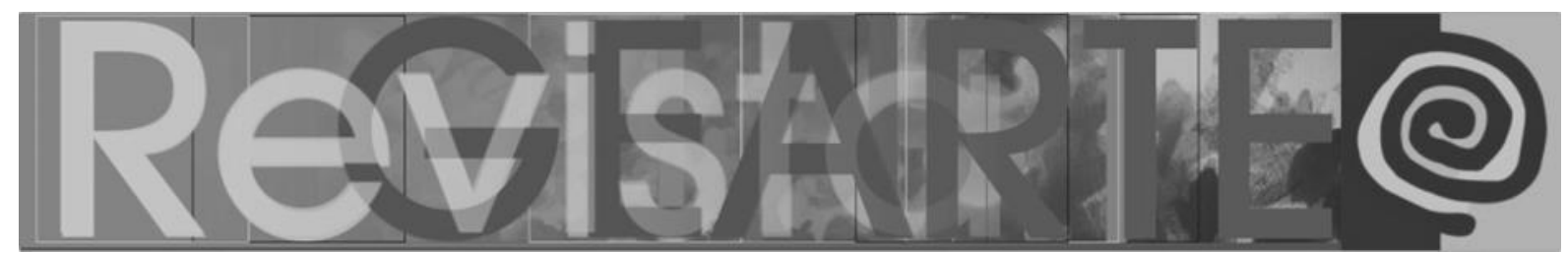

Observei que a pequena utilizava bem de sua imaginação, principalmente ao afirmar que os cabelos da menina que desenhou eram cabelos com cachinhos e no final a ideia rápida que passou pela sua mente de desenhar uma caixa de som, como se a menina e o coelho estivessem escutando uma música e dançando.

Figura 6 - Observando Laila (4a)

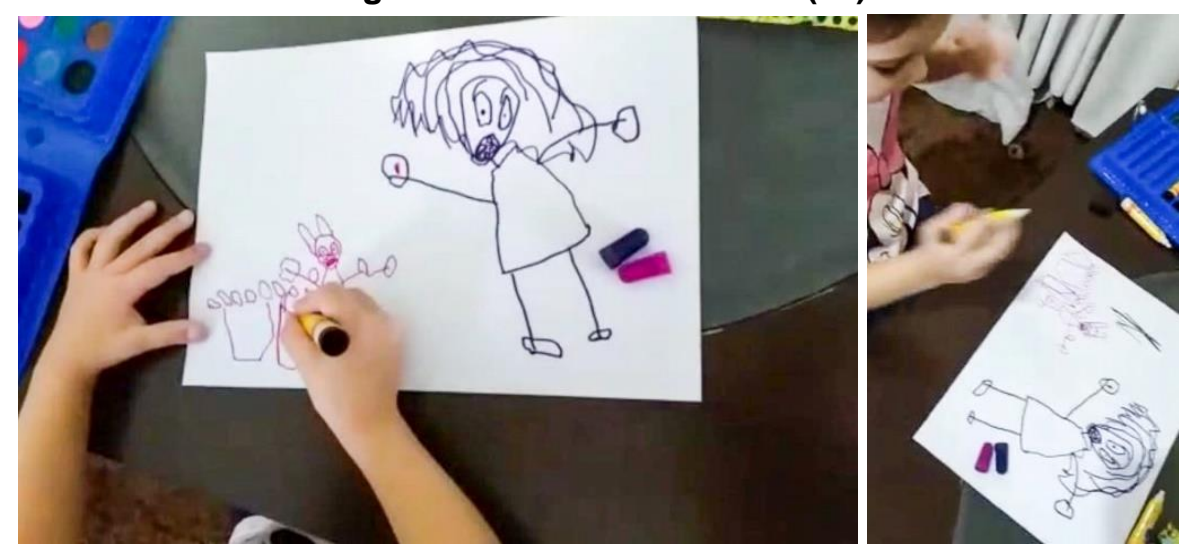

Fonte: Carolina Ribeiro de Souza, 2020.

É interessante notar que Carolina não escreve em seu relatório, mas conta ao grupo na nossa aula on-line que, ao final, a criança de 4 anos faz traços como "o movimento do som" que faz saindo da caixa de som desenhada perto do coelho. Envia depois o vídeo com o movimento que a criança faz. A linha se torna som e todos dançam...

Há muito exemplos que poderiam ser apresentados. Todos os desenhos e suas observações geraram muitas conversas com as três turmas nos dois últimos semestres. Presencialmente ou nas aulas on-line em tempos de isolamento social, a leitura das observações gerou surpresas, especialmente em relação às garatujas e às histórias contadas pelas crianças. Puderam perceber como a documentação pedagógica amplia a percepção, pois o ato de escrever alimenta também o olhar e relembrar o que foi e como foi realizada a ação de desenhar. A percepção de processos vividos é muito mais rica do que a leitura de produtos e, ao voltar aos textos sobre a metamorfose da produção infantil para estudá-los, a compreensão se faz mais profunda. Perceberam também o contexto do momento, as escolhas dos materiais oferecidos, os diferentes procedimentos corporais (sentados no chão, à mesa), os temas que apareceram, os modos de documentar o processo, 


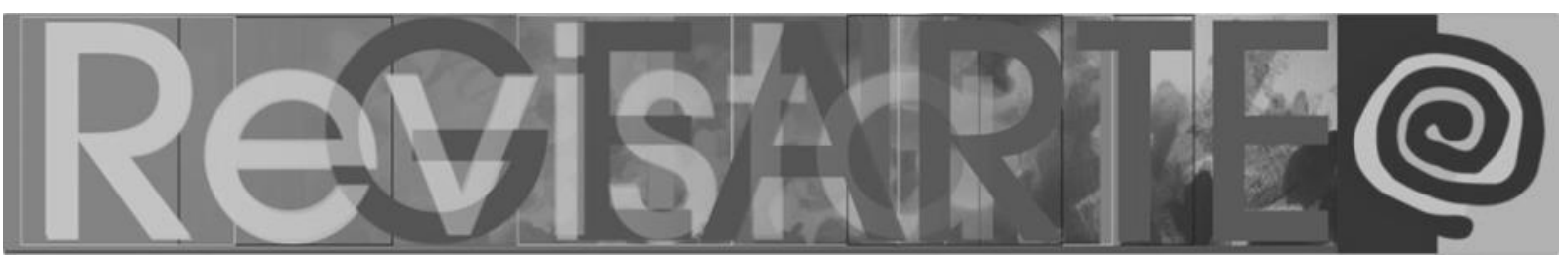

as falas das crianças e suas histórias e interesses pessoais. E se descobriu também o imenso desejo de desenhar heróis...

\title{
“Eu não sei desenhar", os desenhos de colorir, a decepção, frustração e o abandono de processos de criação
}

São muitos os pedidos de ajuda para desenhar. Cada vez mais a imaginação é ampliada pelos filmes na TV e nos celulares... O primeiro impulso é fazer pela criança e, assim, elas logo aprendem os modelitos que os adultos sabem fazer: homens palito, árvores/sorvete, "aquelas" casinhas... E assim, logo aprendem que eles não sabem mesmo fazer e alguém deve ensinar... E isso é tão forte que carregamos para a vida, buscando modelos e os consumindo sem pensar...

Em um dos textos se lê: "Na observação, senti dificuldade em não interferir e não palpitar em nada, como quando Marcos perguntou como ele poderia fazer um cachorro. No instinto, eu logo iria demonstrar, mas precisei falar para fazer do seu jeito". Segurar a própria ansiedade parece ser uma ação bem difícil... Stephanie Kimiye Omori, em 2019, conta o que aprendeu...

\begin{abstract}
Logo de cara [o menino de 4 anos] se mostrou muito interessado em desenhar o Batman. Foi muito enriquecedora a experiência, pois logo no começo já me deparei em situações da criança dizendo que não sabe fazer. Queria que eu lhe dissesse como desenhar a máscara do Batman. Poderia fazer que nem no texto "O menininho" e simplesmente mostrar para ele o que fazer, porém queria que ele desenhasse da imaginação dele. Então fingi que não sabia e perguntei: como é a máscara do Batman? Ele me descreveu com tantos detalhes que logo foi tentando fazer. E a mesma coisa com a camiseta do Batman. Então falei pra ele olhar as camisetas que as pessoas estavam usando e imaginar a que ele queria desenhar. Mostrou dificuldade em desenhar um morcego, foi quando lembrei do que a professora Miriam citou em aula de mostrar no máximo uma imagem real do que a criança quer e deixar ela fazer do jeito dela, por isso mostrei a imagem do morcego e o Pedro logo foi fazendo sem precisar de nem um exemplo meu. No fim o desenho ficou muito melhor do que eu esperava, com detalhes do cinto e tudo. Mas o interessante é que quando ele achou que tinha errado um pequeno detalhe no desenho, logo quis pegar outra folha e começar de novo. Mas dessa vez a imaginação foi além, decidiu desenhar o Batman criança e o Batman adulto, com o Coringa e o Pinguim, os vilões. E por fim quis desenhar o Batman com a perna quebrada e o Pinguim, que segundo ele é o melhor vilão de todos e o culpado por quebrar a perna do super-herói.
\end{abstract}




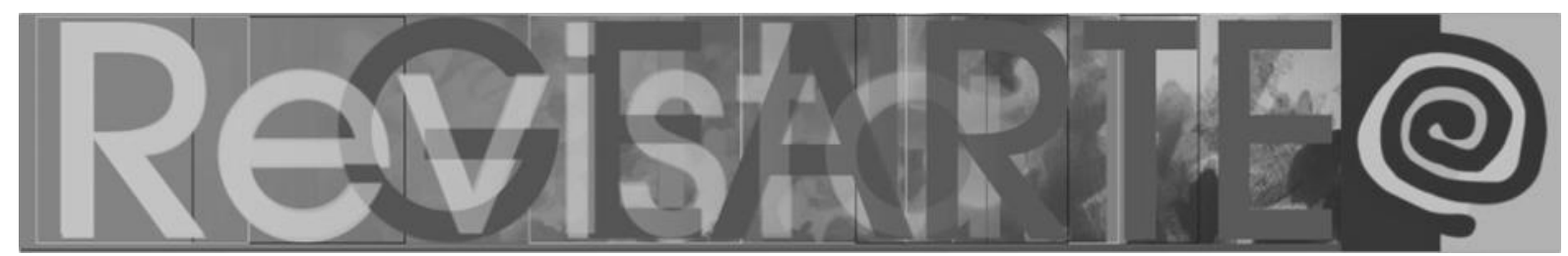

A forma como as cores foram usadas foi interessante também, procurando as cores que achava que eram os personagens. Pedro procurou usar bem o espaço da folha de papel, o que me deixou intrigada.

Figura 7 - O Batman e O Batman com perna quebrada, por Pedro (4a)

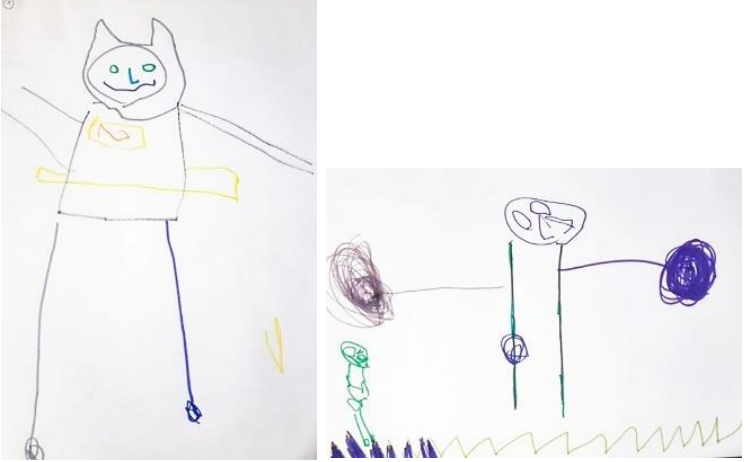

Fonte: Stephanie Kimiye Omori, 2019.

Não basta dizer para fazer do seu jeito, pois isso também é abandonar a criança que deseja um algo a mais. A ação de Stephanie provocando a descrição de como seria a máscara ou como é uma camiseta e mostrando fotografias de um morcego ampliou o olhar da criança. É nesse sentido que podemos oferecer espaço, tempo, materiais, ideias, imagens e confiança para a criança continuar criando. Os menores recriam ao seu modo os personagens que gostam se sentirem confiança em seus próprios trabalhos, se não foram submetidos aos desejos de adultos que querem "ensinar" como fazer em vez de pensar em outro tipo de apoio. Voltaremos a essa questão...

Ana Clara Freitas Oliveira percebeu, em 2020, dois movimentos na observação de um menino de 9 anos que adorava as aulas de arte. No primeiro desenho, ele ficou muito empolgado.

Depois de alguns minutos conversando e construindo sua obra, ele me mostrou o que tinha desenhado. Era um retrato meu. Com o traço forte ele retratou meu cabelo enrolado, meus lábios e inclusive meus óculos retangulares. Assinando seu nome na obra, ele disse que era um presente para mim, para guardar com carinho e lembrar dele.

Inicialmente, Ana Clara tinha apresentado apenas o texto sobre esse desenho, mas como havíamos comentado em aula sobre outra observação, em 


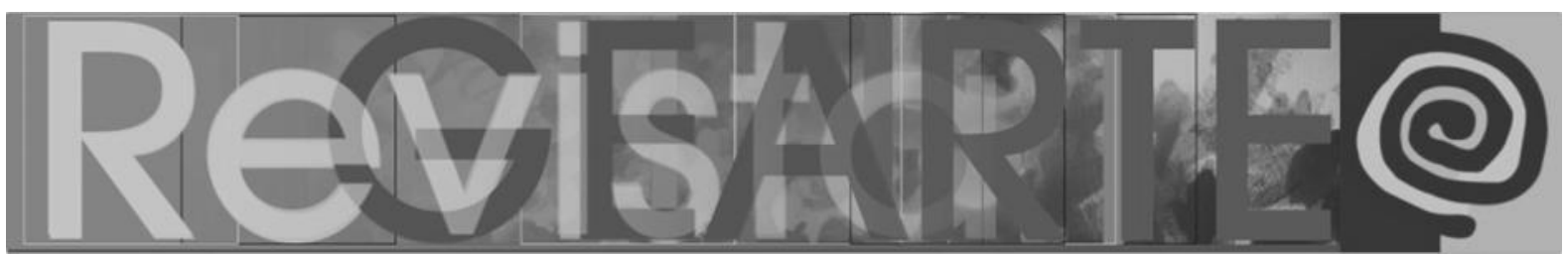

que a criança amassou a folha de papel para fazer um personagem de TV, ela nos contou sobre o desenho no verso e completou o seu texto.

\begin{abstract}
Após fazer um retrato meu, Pedrinho decidiu que iria fazer um outro desenho no verso, pois assim ele utilizaria a folha dos dois lados. [...] Logo em seguida ele pede para que eu procure na internet o desenho do personagem que ele tanto gosta e quer reproduzir, e com a ajuda dele escrevo o nome do jogo e de imediato aparecem várias imagens. Quando se inicia o desenvolvimento, observo que ele fica um pouco apreensivo ao tentar reproduzir a cabeça do personagem. Uma dificuldade comum em fazer um círculo perfeito, mas logo após movimentar o corpo todo para completar o círculo percebe que não ficou do jeito que gostaria e tenta desenhar o cabelo do personagem. Ele se decepciona, pois não ficou do modo como ele esperava e então pede para que pinte com ele um livro para colorir.
\end{abstract}

Essa situação não é rara, infelizmente. Desejo de copiar, a frustração e o abandono do desenho. E a fuga é colorir desenhos que podem ser escolhidos entre milhares de opções na internet ou simplesmente desistir. Há outras crianças que mostraram desenhos para colorir ofertados por seus pais. São atividades propostas apenas como tarefas a serem cumpridas, sem significado nenhum, realizadas pelas crianças com certa alegria, já que se tornam, por vezes, a única possibilidade de trabalhar com cores. Na falta de conhecer outras opções, velhos modelos para superar o "Eu não sei. Eu não tenho jeito!".

A observação de Carolina David Ramos, de 2020, inicia-se falando de sua própria experiência.

Com o texto 'O menininho', consegui refletir e me enxergar no personagem do conto. Sempre tive uma ligação especial com a arte, em especial os desenhos. Já ganhei muitos concursos, conseguia expressar tudo aquilo o que eu sentia em minhas obras artísticas. Porém, algumas coisas mudaram a partir do momento em que eu entrei em um curso de desenho na frente da minha escola. Lá o professor apenas pedia para eu repetir os movimentos, os traços e os desenhos dele, não possuía liberdade pra criar minhas ideias no papel.

Comecei então a me cobrar cada vez mais, me importar com detalhes que eu não me importava antes, como a grossura da linha, o traço e outras coisas. $\mathrm{O}$ que antes era prazeroso tinha se tornado estressante para mim, desde então parei de desenhar como antes, minha criatividade já não era o suficiente na minha consciência, e possuo reflexos disto até hoje em minha personalidade. Portanto, até conseguimos aprender um pouco, em um modelo de cópia, porém não é o mais eficiente. Esse modelo não desenvolve a criatividade e o lado artístico da criança, ao contrário, o reprime. 


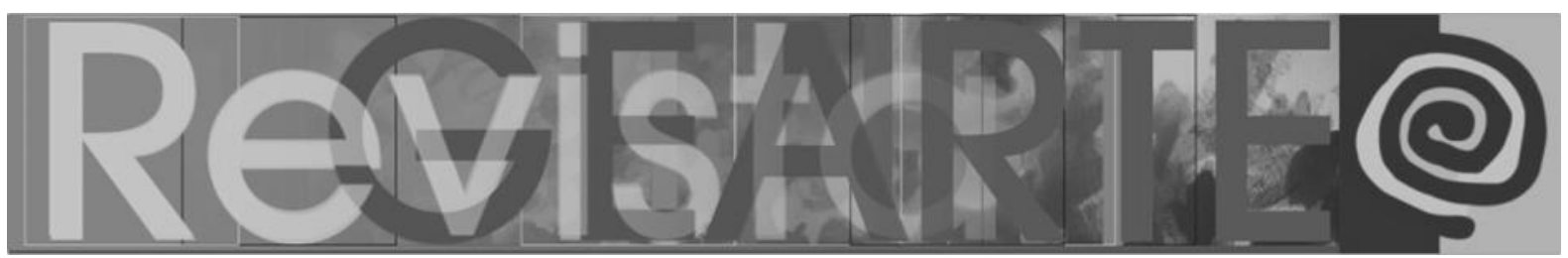

Carolina tem mostrado muita criação em suas ações poéticas e espero que possa superar os traumas de um mau professor de arte. Frustração e abandono. Perceber suas próprias decepções com sua produção pode ajudar a compreender o caminho que está sendo percorrido pelas crianças que esperam modelos, buscam que outros desenhem por ela ou apenas colorem desenhos... O que fazer? É adequado apenas valorizar a produção e dizer para fazer de seu próprio jeito?

\title{
Intervenções para provocar desafios estéticos
}

Tenho dito que tenho alergias pedagógicas com as palavras "atividade" e "aplicação" (MARTINS, 2019). Com frequência, atividades valem por si mesmas e pouco se articulam com as demais. Atividades são aplicadas (assim como muitos projetos), listadas, copiadas ou recriadas, mas nem sempre são escolhidas tendo em vista as crianças que vão fazê-las.

\begin{abstract}
É preciso conhecer as crianças reais e concretas do dia a dia, além dos manuais de Pedagogia ou Psicologia, pois como nos diz o pedagogo que inspirou a proposta educativa das escolas de infância de Reggio Emilia, 'as coisas relativas às crianças e para as crianças somente são aprendidas através das próprias crianças' (MALAGUZZI, 1999, p. 61). É imprescindível estar com elas, olhá-las, escutá-las. Mas como captar suas vozes, incluindo as que não falam? A observação cuidadosa das crianças é essencial para poder conhecê-las e respeitá-las, para compreender o que dizem além das palavras (OSTETTO, 2018, p. 50).
\end{abstract}

Conhecer as crianças é fundamental. Além da observação/escuta cuidadosa e sensível, é necessário criar situações de aprendizagens, isto é, contextos em que as ações possam oferecer experiências concretas que levem a uma aprendizagem, seja pela exploração, seja pela pesquisa ou pela ampliação de conhecimentos.

Lara Joyce Martins Silva, por exemplo, percebeu, em 2019, a dificuldade de desenhar figuras humanas de uma criança de 8 anos que tem um atraso de desenvolvimento global em estágio leve. E brincou com ela na construção de figuras com massinha e com modelagem de papel, ampliando sua percepção, por exemplo, das cores das peles... "Nos desenhos a lápis, vi que ela fazia tudo com muita pressa, inclusive pintar, mas nesse boneco ela pintou com bastante calma $\mathrm{e}$ 


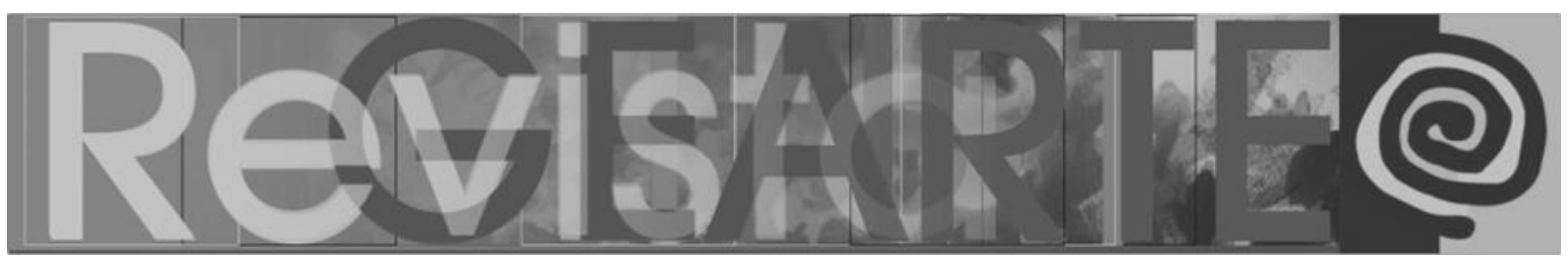

dedicação." A mudança para o tridimensional fez a diferença! Uma escolha que ampliou a compreensão pelo desafio de explorar outra materialidade e sair do papel A4.

Stephanie Kimiye Omori, em 2019, brincou com seu priminho escondendo folhas de papel e o que gostou mais foi desenhar deitado no chão no papel que estava colado por baixo do assento da cadeira. É como pintar o teto da Capela Sisitina.

Mariana Chiaradia Monteiro descobre o interesse de seu sobrinho de 9 anos, com características autistas. Ela o leva até o Museu do Transporte, em 2019, e consegue uma visita a uma cabine de metrô. Ele se sente pilotando... Outros detalhes apareceram nas novas produções.

Pensar intervenções após observações atentas e sensíveis tem levado a um maior interesse de estudar, pesquisar e explorar aspectos antes dirigidos apenas aos temas e ao pedido: "desenhe do seu jeito!". É aí que parece estar fazendo mais sentido a compreensão do conceito de alguns textos que foram lidos sobre metamorfose expressiva em Martins, Picosque e Guerra (2010), o pesamento visual de Arnhein (1985), o conceito de zona real e proximal de Vygotsky por meio de um texto que haviam lido em outra disciplina no semestre anterior, para retomar o que já tinham lido (GAMEZ, 2013), além de leituras de desenhos e falas das crianças trazidas por Silvana Augusto (2014), um saboroso diálogo sobre Van Gogh apresentado por Susan Rangel Vieira da Cunha em sua tese (2005) e algumas propostas já vividas em processos de formação continuada.

Com esta turma agora iremos aprofundar as metodologias, como a abordagem triangular proposta por Ana Mae Barbosa $(1991,1998)$. Por vezes tão mal compreendida, a abordagem pode ampliar processos de criação, assim como fez Mariana com seu sobrinho, levando-o ao Museu do Transporte e ao metrô, ou o que fez Francisca Monteiro de Oliveira ao levar obras de Degas para Artur, que tinha desenhado uma incrível bailarina. Não para releituras, mas para ampliação 


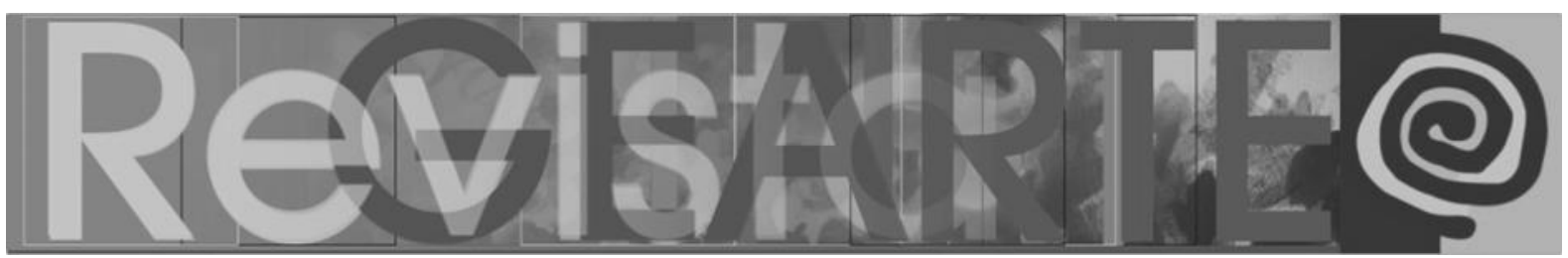

do olhar, pois como disseram Arnaldo Antunes e Paulo Tatit (1995): "O seu olhar melhora o meu".

A abordagem triangular, a pedagogia da escuta, a compreensão de ações poéticas como situações de aprendizagem, especialmente na ampliação da materialidade oferecida, está sendo ampliada também, neste semestre de modo especial, com a cartografia dos territórios da arte e cultura.

Apresentei-a a partir do design utilizado na DVDteca do Instituto Arte na Escola ${ }^{6}$ e para cada território - materialidade; forma-conteúdo; linguagens da arte; processos de criação; saberes estéticos e culturais; patrimônio cutural; mediação cultural; conexões transdisciplinares - fiz muitas sugestões, tentando trazer uma ampla gama de ideias. Entretanto, muitas entregaram propostas mais simples, pouco utilizando a enorme quantidade de ideias apresentadas em uma das aulas on-line. Assim, com o objetivo de ampliar o olhar delas no nosso último encontro (antes de três semanas de férias antecipadas devido ao Covid 19), parti das observações e das intervenções planejadas por elas para sugerir uma cartografia de potencialidades. Não para que as seguissem, mas para abrirmos horizontes possíveis.

Trago aqui um exemplo. Carolina David Ramos, em 2020, observou seu primo de 8 anos. No desenho observado, vê-se um coração enorme e tridimensional que foi complementado depois, conforme escreve em seu relato.

Yuri começou a desenhar outras coisas em seu desenho. Desenhou o Hulk, personagem dos Vingadores que ele ama, desenhou outros corações, um sol, uma nuvem e a lua. Fez uma seta apontando para o coração e ao seu lado escreveu "Arte", sempre usando cores diferentes e alegres.

Em sua proposta, a partir dos conceitos estudados, ela planeja:

[...] deixá-lo mais à vontade, oferecendo maior quantidade de materiais não usados habitualmente, como tintas, massinhas, para desenhar de maneira mais natural possível. [...] Poderia auxiliar o Yuri a se desprender do modelo do Hulk já preestabelecido em sua consciência. Poderia trabalhar primeiramente com o lúdico, propondo alguma brincadeira que 


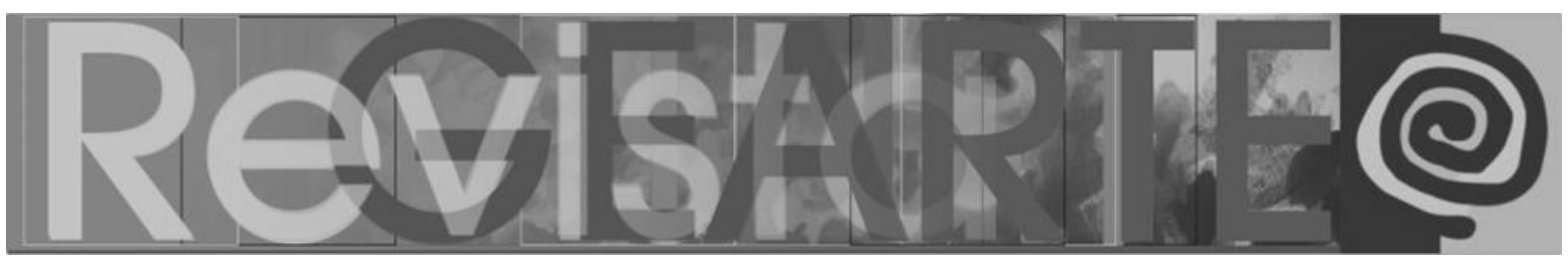

envolvesse heróis para depois pedir a ele uma criação de um herói próprio, sem precisar copiar modelos já existentes.

Pensando a partir de sua observação, apresentei a cartografia abaixo como nutrição estética para alimentar a própria criação. Tive de pesquisar seus criadores e descobri aspectos muito interessantes que desconhecia. Conhecer o processo de criação de Jack Kirby, desenhista do Hulk que também criou outros personagens, visitar virtualmente o seu museu e também o Museu da Imagem e do Som de São Paulo (MIS) e a exposição dos Quadrinhos e tantas outras lá exibidas, além de experimentar no corpo os movimentos dos heróis e criar pequenos filmes em slow motion, pode levar Yuri a perceber a arte por outro viés, pode também ampliar a compreensão da intrínseca relação entre o cotidiano, a cultura e a vida e reaproximar Carolina da arte novamente.

Figura 8 - Cartografia de ideias tendo em vista o interesse da criança (8a) pelo Hulk a partir dos territórios utilizados na DVDteca Arte na Escola

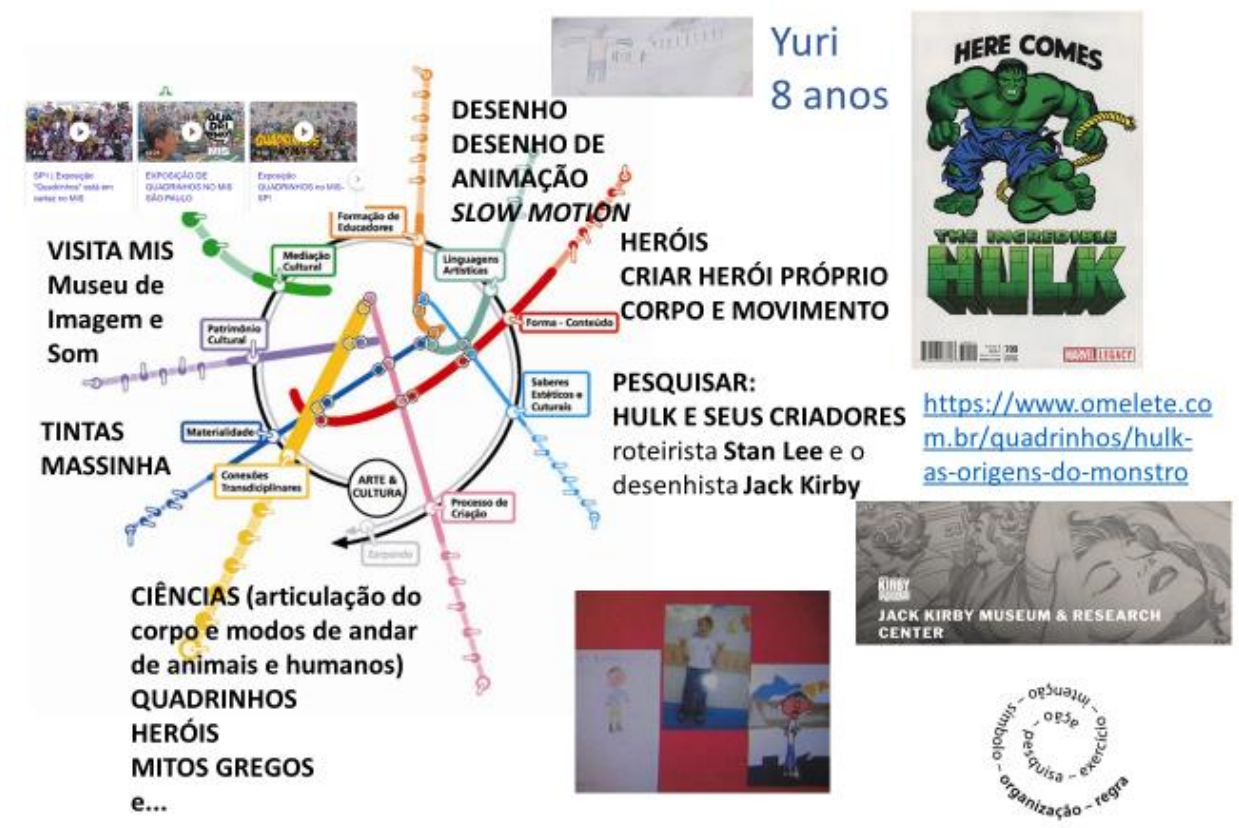

Fonte: Mirian Celeste Martins, 2020.

Essas ideias e tantas outras cartografias sugeridas foram avaliadas como muito positivas por todas, abrindo caminhos impensados... Foi uma suspresa para elas. Imagino que a primeira apresentação que fiz só foi compreendida quando mostrei mais exemplos a partir das observações e das análises que tínhamos feito 


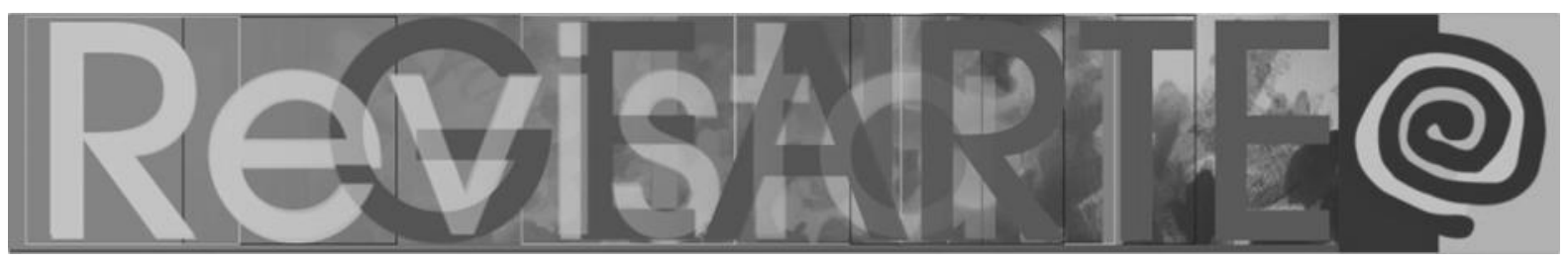

juntas. O tempo que nos resta no semestre atribulado pela Covid 19 não permitirá que o planejamento se concretize por inteiro, mas, certamente, moverá novas ações e atitudes. Também eu me coloco aqui de ponta-cabeça, pensando pelo olhar delas e movendo a potencialidade da inventividade que não tem limites.

\section{Pelos olhos de aspirantes e professora}

Muitos e muitos conceitos foram apenas esboçados aqui e abrem fendas para novos estudos e pesquisas. Verem-se como aspirantes a professoras e professores pode ser um caminhar sem frente e verso como numa fita de Moebius, mergulhando na ação na mesma incerteza de quem é artista propositora como Ligya Clark. Tornar-se um professor-propositor, sensível, atento, pesquisador, é o desejo na formação inicial no Curso de Pedagogia. Ideias que carrego junto a muitos professores que convivem comigo em grupos de pesquisa, congressos e tantos encontros de formação, que é sempre continuada, pois nunca se encerra.

Enquanto fazíamos essas observações e análises em uma aula on-line, pedi uma foto com zoom de qualquer coisa que chamasse a atenção de cada uma em suas casas, sem precisarem levantar-se das cadeiras em que estavam. Por WhatsApp, ia recebendo e comentando sobre os elementos da linguagem fotográfica, especialmente a questão do enquadramento, do foco, do espaço, do ângulo da máquina. As fotos foram sendo cada vez mais e mais elaboradas. Para outra semana, pedi uma nova encomenda: uma foto do mesmo lugar, juntando mais um elemento da linguagem da fotografia, a iluminação. Dessa ação poética retiro cinco imagens que, de certo modo, expõem o estudo, a natureza, a tecnologia, o recolhimeto da casa. Caderno, concha, o mouse e os detalhes da maçaneta e da estante, assim como a lumiosidade da janela aberta, da luminária e da vela, dão testemunho da qualidade de um olhar que poetiza a vida. 


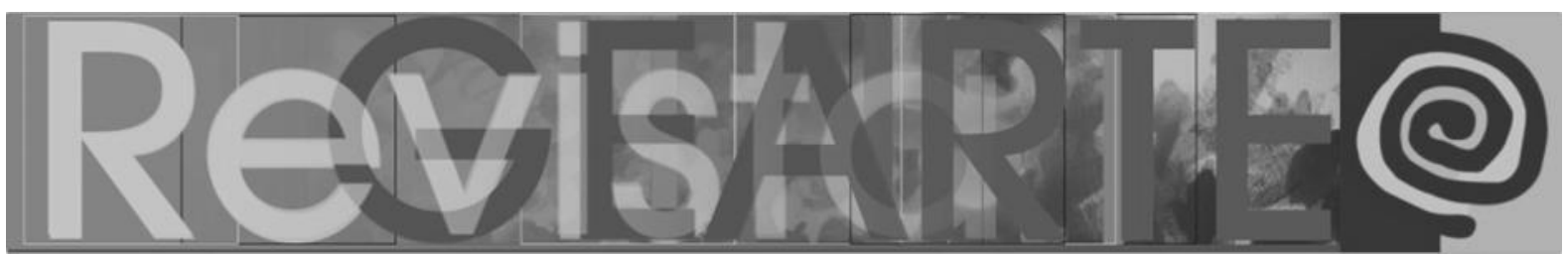

Figura 9 - Fotografias como resultado da encomenda: Exercício do olhar do fotógrafo em casa na quarentena

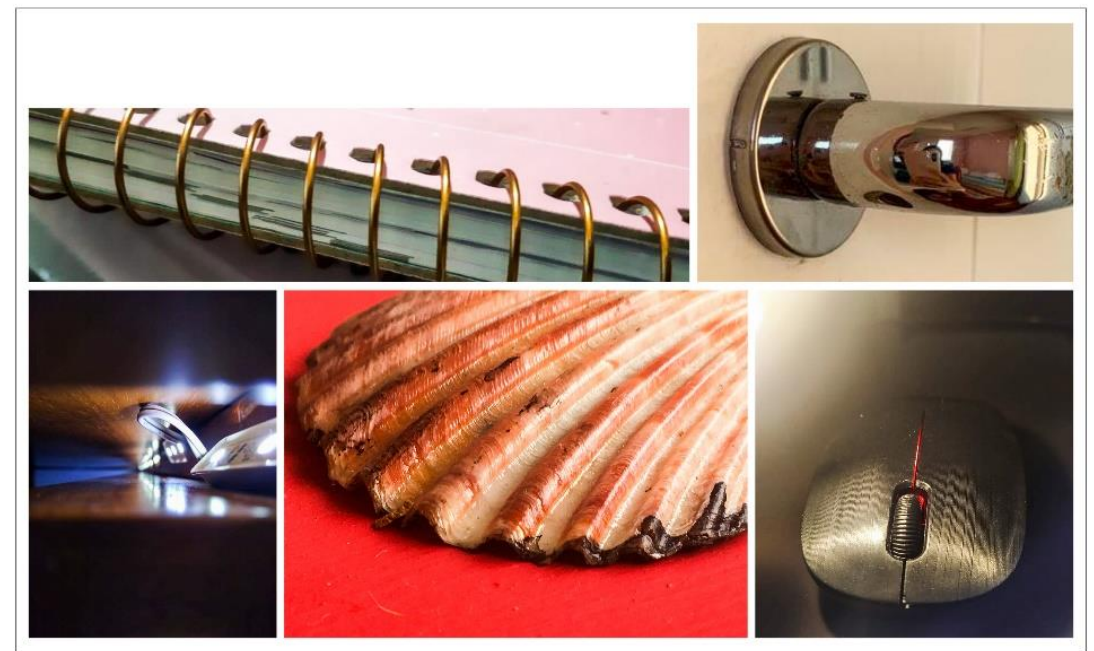

Fonte: Vivian de Oliveira Cavicchioli, Ana Carolina G. de Andrade, Ana Clara F. Oliveira, Camila P. Ferreira da Costa e Carolina David Ramos, 2020.

As observações cuidadosas e as fotografias sensíveis me fazem lembrar as qualidades apontadas por Carl Leggo e Rita Irwin (2013, p. 153): “De acordo com Berman (1999), essas qualidades incluem: (a) dar voz ao não dito, (b) acolher o mistério, (c) conectar diálogos entre coração/mente, (d) tornar-se testemunha e (e) deliciar-se com a surpresa". A autora citada no texto esceveu "O professor como poeta" acreditando que as qualidades são pertinentes ao poeta e à poesia, assim como aos professoras/es e ao ato de ensinar.

Ao revelar sensíveis olhos-pensantes, de ponta-cabeça, vibro com as descobertas que fizeram e vão contiuar a fazer, na crença de que pemitam que a arte e a cultura penetrem em suas vidas como penetraram nas nossas de professores, isso porque, outros antes de nós também nos ensinaram a ir além!

\section{Notas}

1 Fragmentos do vídeo disponível em: https://www.youtube.com/watch?v=19rE54nC8V4\&feature=youtu.be. Acesso em: 22 abril 2020.

2 Texto que acompanha as belas imagens do vídeo de Marcia Strazzacappa: "Em 2020, o mundo virou de ponta-cabeça./ Havia duas opções, cair no abismo ou aprender a voar... Passei a observar o céu, a sentir a brisa, a ver o vento esculpir nuvens./ Comecei a perceber os diferentes tons de azul e a sutil nuance das cores./ Na ausência de asas/ aprendi a caminhar sobre as nuvens./ Um passo 


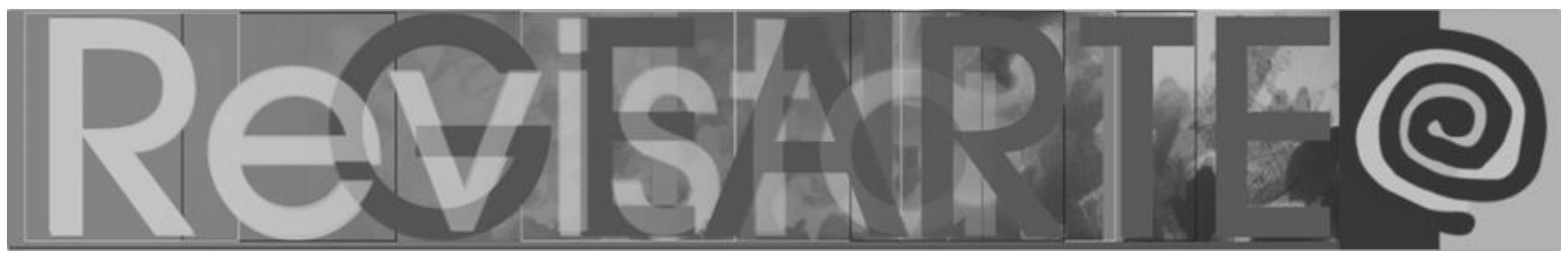

por vez./ Quando me senti segura, ensaiei redemoinhos/ e dancei sobre as nuvens até o anoitecer. Que da queda, seja feita uma dança./ E da crise, renovação!".

3 Trago também a experiência com a formação continuada de educadores em muitas instituições, como o Espaço Pedagógico (1992-2005), coordenado por Madalena Freire, Juliana Davini, Fátima Camargo e por mim, além de muitos dos trabalhos desenvolvidos junto à Secretaria de Estado de Educação/SP, ao Instituto Arte na Escola, ao Rizoma Cultural na parceria com Gisa Picosque, além de muitos outros.

4 A sua tese encontra-se em fase final de produção neste momento e tem como título: Social STEAM MAKER, do digital ao barro: Tecnologia social, integrativa e prática para Educação no Ensino Médio.

5 Em 27/02/2020, Rita Irwin escreveu em seu e-mail: "Student teacher emphasizes 'student' and we wanted our students to take on the responsibility of being a teacher earlier - not that we expect them tone teachers - thus calling them teacher candidates. We have found it helps them think more seriously about what they are embarking upon. So no I did not create it and I can't give you an original attribution. Our Faculty uses it with our students who are in the teacher education program where they are aiming to become teachers".

6 UMA GARATUJA são só rabiscos? Vídeo. Disponível em: www.mirianceleste.com.br. Acesso em: 27 fev. 2021.

7 A proposta da DVDteca do Instituto Arte na Escola foi criada por Gisa Picosque e por mim. Há vídeos que apresentam a proposta da cartografia rizomática. Disponível em: http://artenaescola.org.br/dvdteca/. Acesso em: 10 abr. 2020.

\section{Referências}

ARNHEIN, Rudolf. El pensamiento visual. Buenos Aires: Eudeba, 1985.

AUGUSTO, Silvana de Oliveira. Ver depois de olhar: a formação do olhar dos professores para os desenhos das crianças. São Paulo: Cortez, 2014.

BARBOSA, Ana Mae. A imagem no ensino da arte: anos oitenta e novos tempos. São Paulo: Perspectiva, 1991.

BARBOSA, Ana Mae. Tópicos utópicos. Belo Horizonte: Ed. Com/Arte, 1998.

$\mathrm{BONCl}$, Estela Maria de Oliveira. Formação cultural e artística de estudantes de Pedagogia: constelações potenciais. 2018. Tese (Doutorado em Educação, Arte e História da Cultura) Universidade Presbiteriana Mackenzie, São Paulo, 2018. Disponível em: http://tede.mackenzie.br/jspui/handle/tede/3569. Acesso em: 18 abr. 2020.

BUCKLEY, Helen. O menininho. LEPTRANS, Rio de Janeiro, 2005. Disponível em: http://www.ufrrj.br/leptrans/arquivos/O_menininho.pdf. Acesso em: 10 jun. 2021.

CAMINHANDO com tim tim. Vídeo e texto de Genifer Gerhardt. [S.I.: Tiago Expinho], 2014. 1 vídeo (5 min). Publicado pelo canal Ines Cozzo. Disponível em: https://www.youtube.com/watch?v=UU5hkBH2rw. Acesso em: 13 abr. 2021.

CARERI, Francesco. Caminhar e parar. São Paulo: Gustavo Gili, 2017.

COM OS PÉS no chão. [S.ı.: Marcia Strazzacappa], 2020. 1 vídeo (4 min). Publicado pelo canal Marcia Stazzacappa. Disponível em: https://www.youtube.com/watch?v=19rE54nC8V4\& feature=youtu.be. Acesso em: 13 abr. 2021.

CUNHA, Susana Rangel Vieira da. Educação e cultura visual: uma trama entre imagens e infância. 2005. Tese (Doutorado em Educação) — Universidade Federal do Rio Grande do Sul, Porto Alegre, 2005. Disponível em: https://www.lume.ufrgs.br/handle/10183/79457. Acesso em: 10 fev. 2020.

DEWEY, John. Arte como experiência. São Paulo: Martins Fontes, 2010. 


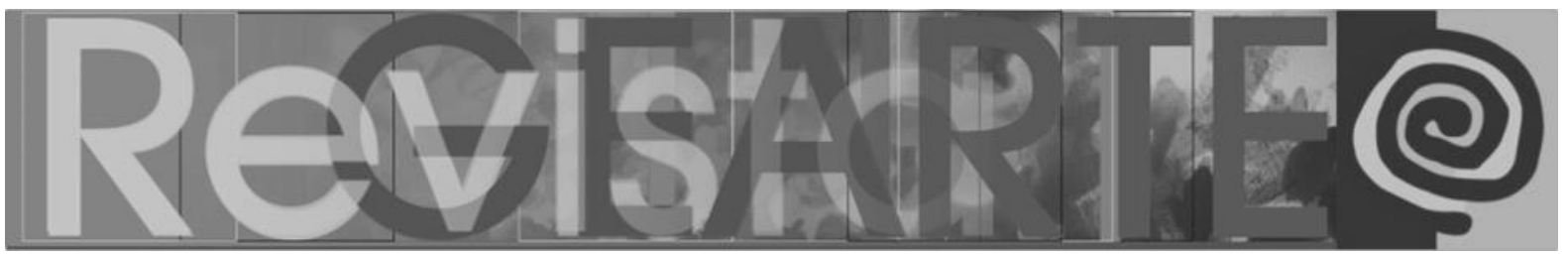

DIAS, Belidson; IRWIN, Rita. (org.) Pesquisa Educacional Baseada em Arte: a/r/tografia. Santa Maria: EdUSFM, 2013.

DVDteca Arte na Escola. São Paulo: Instituto Arte na Escola, 2020. Disponível em: http://artenaescola.org.br/dvdteca/. Acesso em: 10 abr. 2020.

GAMEZ, Luciano. Psicologia da Educação. Rio de Janeiro: LTC, 2013.

GARDNER, Howard. Arte, mente e cérebro: uma abordagem cognitiva da criatividade. Porto Alegre: Artmed, 1999.

IRWIN, Rita. [About "teacher candidate']. Destinatário: Mirian Celeste Martins. Brasil, 27 fev. 2020. E-mail.

IRWIN, Rita. A/r/tografia: uma mestiçagem metonímica. In: BARBOSA, Ana Mae; AMARAL, Lilian. (org.) Interterritorialidade: mídias, contextos e educação. São Paulo: SENAC, 2008. p. 87-104.

IRWIN, Rita. Becoming A/r/tography. [Adaptado de] BNational Art Education Association, 2016. Disponível em: http://nevelestudomany.elte.hu/downloads/2016/nevelestudomany_2016_1_2336.pdf. Acesso em: 20 abr. 2020.

KELLOG, Rhoda. Analisis de la expresión plástica del preescolar. Madri: Cincel, 1985.

LAROSSA, Jorge. Estudar. Belo Horizonte: Autêntica, 2003.

LEGGO, Carl; IRWIN, Rita. A/r/tography: always in process. In: ALBERS, Peggy; HOLBROOK, Teri; FLINT, Amy Seely. New methods in Literacy Research. New York: Routledge, 2013. p. 150-162.

LOVE hair. [S.I: Mathew Cherry], 2019. 1 vídeo (7 min). Publicado pelo canal Sony Pictures Animation. Disponível em: https://www.youtube.com/watch?v=kNw8V_Fkw28. Acesso em: 5 fev. 2020.

LOWENFELD, Viktor; BRITTAIN, William Lambert. Desenvolvimento da capacidade criadora. São Paulo: Mestre Jou, 1977.

MARTINS, Mirian Celeste. Antídotos para "alergias pedagógicas": a ação e o conceito muito além da atividade e do conteúdo, In: ENCONTRO NACIONAL DA ASSOCIAÇÃO NACIONAL DE PESQUISADORES EM ARTES PLÁSTICAS, 28., 2019. Anais [...]. Goiânia: Universidade Federal de Goiás, 2019, p. 2388-2404.

MARTINS, Mirian Celeste. Arte - o seu encantamento e o seu trabalho na educação de educadores: a celebração de metamorfoses da cigarra e da formiga. 1999. Tese (Doutorado em Educação) Universidade de São Paulo, São Paulo, 1999.

MARTINS, Mirian Celeste; BONCI, Estela; MOMOLI, Daniel (org.). Formação de educadores: modos de pensar e provocar encontros com a arte e mediação cultural. São Paulo: Terracota, 2018.

MARTINS, Mirian Celeste; FARIA, Alessandra Ancona de; LOMBARDI, Lucia Maria Salgado dos Santos. (org.) Formação de educadores: contaminações interdisciplinares com arte na pedagogia e na mediação cultural. São Paulo: Terracota, 2019.

MARTINS, Mirian Celeste; LOMBARDI, Lucia Maria Salgado dos Santos. A arte na pedagogia e a formação do professor para educação infantil e anos iniciais: inquietações e esperanças. Revista Trama Interdisciplinar, v. 6, n. 2, 2015. Disponível em: http://editorarevistas.mackenzie.br/index. php/tint/article/view/8350. Acesso em: 18 abr. 2020.

MARTINS, Mirian Celeste; PICOSQUE, Gisa; GUERRA, M. Terezinha. Telles. Teoria e prática do ensino de arte: a língua do mundo. São Paulo: FTD, 2010.

O SEU olhar. Intérprete: Arnaldo Antunes. Compositores: Arnaldo Antunes e Paulo Tatit. In: NINGUÉM. Intérprete: Arnaldo Antunes. [S.I.]: BMG, 1995. 1 CD, faixa 9.

OSTETTO, Luciana Esmeralda. É preciso manter as orelhas verdes: o silêncio e a escuta na educação. In: MARTINS, Mirian Celeste; BONCI, Estela Maria Oliveira; MOMOLI, Daniel. Formação de educadores: modos de pensar e provocar encontros com a arte e mediação cultural. São Paulo: Terracota, 2018. p. 48-64. 


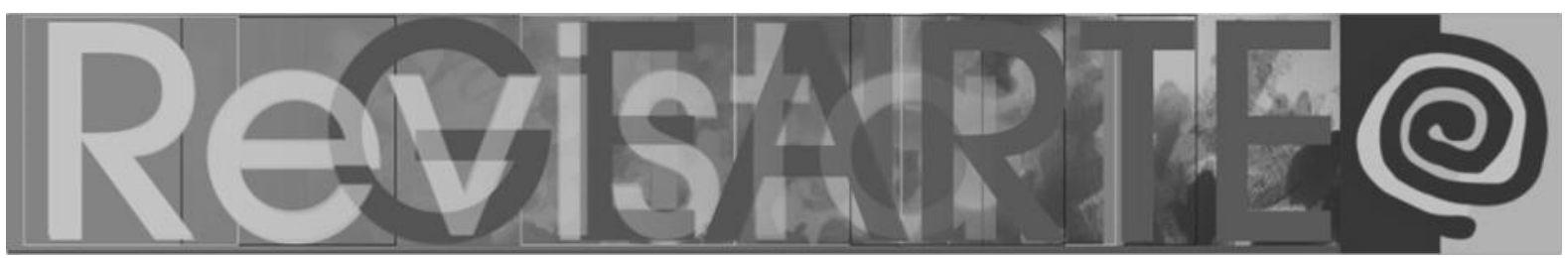

PAREYSON, Luigi. Os problemas da estética. São Paulo: Martins Fontes, 1994.

PIAZZI, Pierluigi. Aprendendo Inteligência. São Paulo: Aleph, 2008. Disponível em: https://edisciplinas.usp.br/pluginfile.php/753234/mod_resource/content/1/PIAZZI\%20Pierluigi\%20 Aprendendo\%20intelig\%C3\%AAncia.pdf. Acesso em: 30 mar. 2020.

ROGOFF, Irit. El Giro. Arte y políticas de identidad, v. 4, p. 253-266, jun. 2011. Disponível em: http://revistas.um.es/api/article/viewFile/146111/130521. Acesso em: 20 abr. 2020.

\section{Mirian Celeste Martins}

Professora do Curso de Pós-graduação em Educação, Arte e História da Cultura e do curso de Pedagogia da Universidade Presbiteriana Mackenzie onde lidera dois grupos de pesquisa: GPAP Arte na Pedagogia e GPeMC - Mediação cultural: provocações e contaminações estéticas. Conselheira da América Latina junto à INSEA - International Society of Education through Art. Mestre em Artes pela ECA/USP e doutora em Educação pela Faculdade de Educação/USP.

ORCID: https://orcid.org/0000-0002-3418-0471

E-mail: mcmart@uol.com.br

Currículo: http://lattes.cnpq.br/7167254305943668

Recebido em 22 de fevereiro de 2021 Aceito em 20 de abril de 2021 